OPEN ACCESS

Edited by: Lucia A. Seale,

University of Hawaii, United States

Reviewed by:

Wen-Hsing Cheng,

Mississippi State University,

United States

Anna Kipp,

Friedrich Schiller University

Jena, Germany

*Correspondence:

Roger A. Sunde

sunde@nutrisci.wisc.edu

Specialty section

This article was submitted to

Nutrition and Metabolism

a section of the journal

Frontiers in Nutrition

Received: 23 April 2021

Accepted: 14 May 2021

Published: 12 July 2021

Citation:

Evenson JK and Sunde RA (2021) Metabolism of Tracer ${ }^{75} \mathrm{Se}$ Selenium

From Inorganic and Organic

Selenocompounds Into

Selenoproteins in Rats, and the

Missing ${ }^{75}$ Se Metabolites.

Front. Nutr. 8:699652.

doi: 10.3389/fnut.2021.699652

\section{Metabolism of Tracer ${ }^{75} \mathrm{Se}$ Selenium From Inorganic and Organic Selenocompounds Into Selenoproteins in Rats, and the Missing ${ }^{75}$ Se Metabolites}

\author{
Jacqueline K. Evenson and Roger A. Sunde* \\ Department of Nutritional Sciences, University of Wisconsin, Madison, WI, United States
}

We now know much about selenium (Se) incorporation into selenoproteins, and there is considerable interest in the optimum form of Se for supplementation and prevention of cancer. To study the flux of ${ }^{75} \mathrm{Se}$ into selenoprotein, rats were fed 0 to $5 \mu \mathrm{g} \mathrm{Se} / \mathrm{g}$ diet as selenite for $50-80 \mathrm{~d}$ and injected iv with $50 \mu \mathrm{Ci}$ of ${ }^{75}$ Se-labeled selenite, selenate, selenodiglutathione, selenomethionine, or selenobetaine at tracer levels ( $\sim 0.5 \mu \mathrm{g} \mathrm{Se}$ ). The rats were killed at various times and ${ }^{75} \mathrm{Se}$ incorporation into selenoproteins was assessed by SDS/PAGE. These studies found that there is very rapid Se metabolism from this diverse set of selenocompounds to the common intermediate used for synthesis and incorporation of ${ }^{75} \mathrm{Se}$ into the major selenoproteins in a variety of tissues. No selenocompound was uniquely or preferentially metabolized to provide Se for selenoprotein incorporation. Examination of the SDS/PAGE selenoprotein profiles, however, reveals that synthesis of selenoproteins is only part of the full Se metabolism story. The ${ }^{75}$ Se missing from the selenoprotein profiles, especially at early timepoints, is likely to be both low-MW and high-MW selenosugars and related precursors, as we recently found in livers of turkeys fed Se-adequate and high-Se diets. Differential metabolism of different selenocompounds into different selenosugar species may occur; these species may be involved in prevention of cancer or other diseases linked to Se status and may be associated with Se toxicity. Additional studies using HPLC-mass spectroscopy will likely be needed to fully flesh out the complete metabolism of selenium.

Keywords: glutathione peroxidase, SDS/PAGE, selenite, selenomethionine, selenosugar

\section{INTRODUCTION}

We now know much about selenium (Se) incorporation into selenoproteins. Se at the selenide level is metabolized to selenophosphate, esterified to serine while attached to a novel selenocysteine tRNA, and incorporated into the selenoprotein backbone during translation at the position specified by a UGA codon and requiring a $3^{\text {'UTR }}$ stem-loop selenocysteine ( $\mathrm{Sec}$ ) insertion sequence (1-6). At the time the experiments here were conducted, only five mammalian selenoproteins had been identified and characterized: glutathione peroxidase (GPX), plasma selenoprotein P (SELENOP), 
phospholipid hydroperoxide glutathione peroxidase (GPX4), plasma GPX3, and thioredoxin reductase (TXNRD) (7). Cloning and expression of UGA-containing transcripts has now demonstrated that the mammalian selenoproteome consists of 24-25 selenoproteins $(8,9)$.

When these studies were conducted there was considerable interest in the optimum form of Se for supplementation and prevention of cancer (10-12). Both inorganic Se, like selenite, and organic Se, like selenomethionine (SeMet), had been shown to readily provide Se for GPX synthesis (13) and to prevent cancer in animal models (14). Some studies suggested that one form vs. another had differential bioavailability (15) or ability to prevent cancer (11). Dietary methionine (Met) had been shown to modulate Se incorporation from SeMet into GPX $(13,16,17)$ and to prevent mammary tumors (18) because, unlike inorganic forms, intact SeMet is an excellent analog of Met for incorporation into general body proteins in place of Met, thus raising tissue Se content without biochemical activity $(16,17,19)$. Selenobetaine (SeBetaine) as a methylselenol donor has high potency against DMBA-induced mammary tumors but it was postulated that anticarcinogenic effects of SeBetaine might be exerted without metabolism to selenoproteins (20). Se was also known to be toxic at higher levels (21-23), but it was not clear if there were additional selenoproteins that appear only under high Se status or that are associated just with Se toxicity $(24,25)$.

Thus, we developed a procedure using SDS slab gel gradient electrophoresis (SDS/PAGE) that separates and quantitates the various Se-containing protein subunits, including GPX (26). By sacrificing rats at various times after the iv injection of Se into rats, SDS/PAGE can monitor the flux of radioactive Se into and between the various detected selenoproteins. As reported previously only in abstract form, we used this procedure to examine the incorporation of ${ }^{75} \mathrm{Se}$ from selenite (27), selenodiglutathione (28), selenate (29), selenomethionine (30), and SeBetaine (31) in order to study Se metabolism leading to selenoprotein synthesis.

The prevailing thought at the time was that tissue Se is present as Sec in selenoproteins, as SeMet is incorporated into general body proteins, and as low molecular weight (MW) metabolites such as selenide, glutathione-Se intermediates, and methylated forms such as methylselenol (7). Low MW "selenosugar" species - seleno-N-acetyl galactose amine (SeGalNac) - first found in urine has also been found in liver as $\mathrm{CH}_{3}-\mathrm{SeGalNac}$ and GSSeGalNac (32). Note that the Se in these selenosugars is linked to galactose 1-carbon via a Se-C bond. Using HPLC coupled with Se-specific and molecule-specific mass spectroscopy, we recently found these low-MW species in livers of turkeys fed Se-adequate and high-Se diets, but we also found high-MW selenosugar species linked via selenodisulfide bonds ( $\mathrm{Se}-\mathrm{S}$ ) to protein. Surprisingly, more Se was present as the selenosugar moiety in Se-adequate turkey liver, mostly decorating general proteins, than was present as Sec in selenoproteins; with high Se supplementation, these "selenosugar-decorated" proteins were further increased (33). This study on turkey liver shows the power of these approaches and more modern analytical techniques to uncover the full metabolism of Se.
Our hypotheses at the time were that ${ }^{75} \mathrm{Se}$ from injected ${ }^{75} \mathrm{Se}$ selenocompounds would be distributed differently in rats, would result in different ${ }^{75} \mathrm{Se}$-labeling patterns of selenoproteins, and might lead to novel ${ }^{75}$ Se-labeled selenoproteins under high Se status. We found, however, that there were no dramatic differences in ${ }^{75} \mathrm{Se}$ distribution between tissues, and that these selenocompounds were not differentially or preferentially metabolized to provide $\mathrm{Se}$ for selenoprotein incorporation. SDS/PAGE also did not detect ${ }^{75}$ Se-labeling of novel selenoproteins under high Se status. What we did not recognize then was the importance of tissue ${ }^{75}$ Se that was missing from the SDS/PAGE gels.

\section{MATERIALS AND METHODS}

\section{Rat Procedures}

The series of studies reported here were conducted in 19861991 and approved by the following Animal Care and Use Committees: University of Arizona (A3248 \#86-0172 and \#860357), and the University of Missouri (A3394 \#1425). Male Holtzmann weanling rats were fed a basal $30 \%$ torula yeastbased diet that contained by analysis $0.005-0.018 \mu \mathrm{g} \mathrm{Se} / \mathrm{g}$ diet $(26,34,35)$. To prevent liver necrosis, the basal diet was supplemented with $100 \mathrm{IU} / \mathrm{kg}$ of all rac- $\alpha$-tocopheryl acetate (Sigma Chemical Co., St. Louis, MO) at the expense of sucrose. Unless otherwise stated, the basal diet was supplemented with 0.4\% D,L-methionine (U.S. Biochemical Corp., Cleveland, OH), and with $0,0.2,2.0$, and/or $5.0 \mu \mathrm{g} \mathrm{Se} / \mathrm{g}$ diet as selenite for 50 $80 \mathrm{~d}$, depending on the experiment. Rats were anesthetized with ether and injected iv in the femoral vein with $50 \mu \mathrm{Ci}$ of ${ }^{75} \mathrm{Se}$ labeled selenocompounds at trace levels $(\sim 0.5 \mu \mathrm{g} \mathrm{Se})$, and killed $1,3,24$, or $72 \mathrm{~h}$ (also $168 \mathrm{~h}$ for SeMet) after injection as described previously (26). Blood was sampled by cardiac puncture using a heparinized syringe; liver was perfused in situ with $0.15 \mathrm{M} \mathrm{KCl}$ to remove erythrocytes. Plasma was obtained by centrifugation $(1,000 \mathrm{~g} \times 30 \mathrm{~min})$. Tissues were weighed, and portions of tissues were ${ }^{75} \mathrm{Se}$-counted to calculate tissue ${ }^{75} \mathrm{Se}$ recovery. Liver and kidney were homogenized in $9 \mathrm{vol}$ of $0.25 \mathrm{M}$ sucrose, and the cytosolic fractions were prepared by subcellular fractionation. Heart, testes, and muscle (gastrocnemius from uninjected (right) leg) were homogenized in $9 \mathrm{vol}$ of $10 \mathrm{mM}$ Tris, $1 \%$ SDS, and $10 \mathrm{mM}$ 2-mercaptoethanol buffer, $\mathrm{pH}$ 7.4, using a Brinkmann polytron, and the homogenates were centrifuged at $105,000 \mathrm{~g}$ $\mathrm{x} 60 \mathrm{~min}$ to obtain supernatants that were then subjected to SDS/PAGE (26).

\section{SDS/PAGE Procedure}

After preparation, $1,500 \mu \mathrm{g}$ protein was mixed (1:1) with sample buffer (50 mM Tris, 1\% SDS, 2\% 2-mercaptoethanol), heated in a boiling water bath for $15 \mathrm{~min}$, and loaded onto $3 \mathrm{~mm}$ slab gels with an acrylamide gradient from 7.5 to $20 \%$ (top to bottom) and electrophoresed at $60 \mathrm{~mA}$ per gel. The gels were fixed in methanol:acetic acid:water (5:1:4) containing 0.25\% Coomassie brilliant blue $\mathrm{R}$, and destained in methanol:acetic acid:water (75:50:875). Each lane was cut out, sliced into $2 \mathrm{~mm}$ slices, and counted. Protein standards of known MW were run to calibrate position with molecular weight (26). 


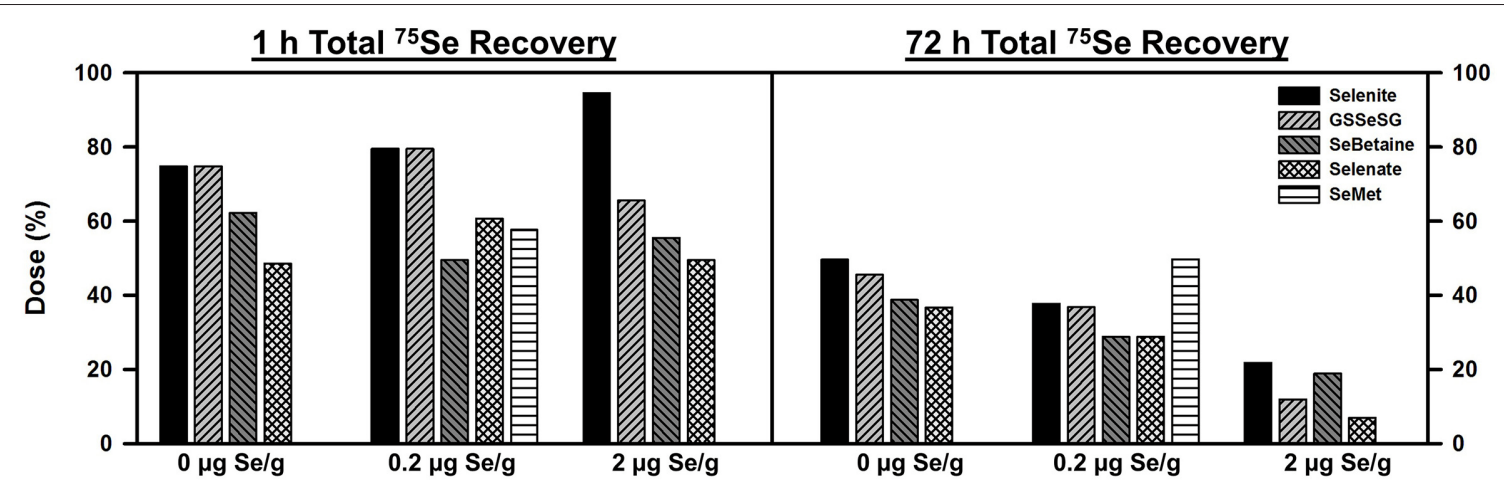

FIGURE 1 | Total ${ }^{75}$ Se recovery at 1 and $72 \mathrm{~h}$ after injection ${ }^{75}$ Se selenocompounds. Rats were fed the indicated dietary Se levels as selenite for $50-80 \mathrm{~d}$, injected iv with $50 \mu \mathrm{Ci}$ of tracer ${ }^{75} \mathrm{Se}$-labeled Selenite, GSSeSG, SeBetaine, Selenate, or SeMet, killed at 1 and $72 \mathrm{~h}$ afer dosing, and ${ }^{75} \mathrm{Se}$ retained in blood, liver, kidney, heart, testes, epididymus, and muscle was counted. Values are the percent of the administered ${ }^{75}$ Se dose recovered $(n=1$ per treatment at each time for each selenocompound, $n=26$ total).

\section{${ }^{75}$ Se Compounds}

$\left[{ }^{75} \mathrm{Se}\right]$ selenite was obtained from commercial sources or produced at the Research Reactor at the University of Missouri. Individual rats were injected with $50 \mu \mathrm{Ci}$ of $\left[{ }^{75} \mathrm{Se}\right]$ selenite $\left.(\sim 0.5 \mu \mathrm{g} \mathrm{Se}) . \mathrm{L}-{ }^{75} \mathrm{Se}\right] \mathrm{SeMet}(1.1 \mathrm{Ci} / \mu \mathrm{mole})$ was obtained from Amersham. $\left[{ }^{75} \mathrm{Se}\right]$ selenodiglutathione was synthesized from $2 \mathrm{mCi}$ of $\left[{ }^{75} \mathrm{Se}\right]$ selenite $(63 \mu \mathrm{Ci} / \mu \mathrm{g} \mathrm{Se})$, which were reduced with $5 \mathrm{mg}$ ascorbate, oxidized with concentrated redistilled $\mathrm{HNO}_{3}$ and then dried at $60 \mathrm{oC}$. The resulting selenite $(0.24$ $\mu$ moles) was reduced with GSH on ice for $16 \mathrm{~h}$ at $\mathrm{pH}<1.0$, using a 4 GSH:1 Se stoichiometry. A sample was analyzed using a Dowex-Ni column, which showed that $97 \%$ of the applied ${ }^{75} \mathrm{Se}$ eluted after GSSG and thus was present as $\left[{ }^{75} \mathrm{Se}\right] \mathrm{GSSeSG}$ (36). $\left[{ }^{75} \mathrm{Se}\right]$ selenobetaine (dimethylselenoacetate, SeBetaine) was synthesized from $2.5 \mathrm{mCi}$ of $\left[{ }^{75} \mathrm{Se}\right]$ selenite $(70 \mu \mathrm{Ci} / \mu \mathrm{g} \mathrm{Se})$ by borohydride reduction, and reacted with iodomethane to produce trimethylselenonium ion. After purification, the trimethylselenonium ion was pyrolyzed to form dimethylselenide, which was reacted with bromoacetic acid to form dimethylselenoacetate. Purification on SP-Sephadex resulted in $>60 \%$ recovery as SeBetaine $(37)$. $\left[{ }^{75} \mathrm{Se}\right]$ selenate was prepared by oxidizing $\left[{ }^{75} \mathrm{Se}\right]$ selenite with $30 \% \mathrm{H}_{2} \mathrm{O}_{2}$. Following oxidation, complexation with 2,3 - diaminonaphthalene, a selenite-specific reaction, showed that $<3 \%$ of the ${ }^{75}$ Se remained as selenite. A Packard model 5650 refrigerated gamma counter with 3 " KI crystal was used for ${ }^{75}$ Se counting (60\% efficiency for $\left.{ }^{75} \mathrm{Se}\right)$.

\section{RESULTS}

Biomarkers of Se status of Holtzmann rats fed these diets have been reported thoroughly by our group and are not reported here. Plasma and liver glutathione peroxidase activities in rats fed the Se-deficient basal diet are typically $2 \%$ of levels found in rats supplemented with $0.2 \mu \mathrm{g} \mathrm{Se} / \mathrm{g}$ diet (35) and are not further increased by $1-5 \mu \mathrm{g} \mathrm{Se} / \mathrm{g}$ diet $(35,38)$. Liver Se concentrations for rats fed the basal Se-deficient diets for 4 wk are typically $0.25 \mathrm{nmol} / \mathrm{g}$ liver $(0.02 \mu \mathrm{g} \mathrm{Se} / \mathrm{g})$ and $3 \%$ of levels in rats fed $0.2 \mu \mathrm{g} \mathrm{Se} / \mathrm{g}$ diet. Liver Se concentration in rats fed 0.2, 2, and $5 \mu \mathrm{g} \mathrm{Se} / \mathrm{g}$ are typically $0.66,2.2$, and $2.9 \mu \mathrm{g} \mathrm{Se} / \mathrm{g}$ liver, respectively (38).

Se status did not have a large effect on ${ }^{75}$ Se recovery, distribution, or retention for any of the compounds tested (Figure 1). At $1 \mathrm{~h}, 75$ to $50 \%$ of the injected ${ }^{75} \mathrm{Se}$ was recovered in blood, liver, kidney, heart, muscle, and testes of these male rats, regardless of the form of Se. Selenite and GSSeSG recoveries were slightly higher than for SeBetaine, selenate, and SeMet at $1 \mathrm{~h}$. By $72 \mathrm{~h}$, total retention in these tissues ranged from 50 to $25 \%$ when injected into 0 and $0.2 \mu \mathrm{g} \mathrm{Se} / \mathrm{g}$ diet rats, but $<20 \%$ for rats fed $2 \mu \mathrm{g} \mathrm{Se} / \mathrm{g}$. At $72 \mathrm{~h}$, total retention in rats fed 5 $\mu \mathrm{g} \mathrm{Se} / \mathrm{g}$ as selenite was $11 \% .{ }^{75} \mathrm{Se}$ recovery from SeMet was only determined in rats fed $0.2 \mu \mathrm{g} \mathrm{Se} / \mathrm{g}$, but appeared higher than for the other forms. For the other four Se compounds, the recoveries at $72 \mathrm{~h}$ in rats fed 0.2 vs. $0 \mu \mathrm{g} \mathrm{Se} / \mathrm{g}$ were only marginally reduced, as compared to the decrease in dietary Se concentration, suggesting that the relative flux of Se in rats fed $0.2 \mu \mathrm{g} \mathrm{Se} / \mathrm{g}$ was little altered as compared to rats fed the Se-deficient diet.

Recovery of injected ${ }^{75} \mathrm{Se}$ in six tissues are shown in Figure 2. Plasma ${ }^{75} \mathrm{Se}$ retention was calculated based on a blood volume of $8 \%$ of total body weight and fraction of blood as plasma (26). At $1 \mathrm{~h}, 20 \%$ of the injected ${ }^{75} \mathrm{Se}$ was found in plasma in rats fed the Se-deficient diet. Supplemental dietary Se at 0.2 and $2 \mu \mathrm{g} \mathrm{Se} / \mathrm{g}$ diet progressively deceased the recovered ${ }^{75} \mathrm{Se}$ in plasma. By $72 \mathrm{~h}$, plasma retained $\sim 10 \%$ of the $\left[{ }^{75} \mathrm{Se}\right]$ selenite in rats fed both 0 and $0.2 \mu \mathrm{g} \mathrm{Se} / \mathrm{g}$ diet, but this was decreased to $5 \%$ with $2 \mu \mathrm{g} \mathrm{Se} / \mathrm{g}$ diet. At $72 \mathrm{~h}$, approximately half as much injected ${ }^{75} \mathrm{Se}$ was retained for the other selenocompounds as compared to selenite.

A different pattern was found for liver as compared to plasma. At $1 \mathrm{~h}$, recovery of ${ }^{75}$ Se from selenite doubled in rats fed 2 vs. $0 \mu \mathrm{g} \mathrm{Se} / \mathrm{g}$, and recoveries of ${ }^{75} \mathrm{Se}$ from GSSeSG, SeBetaine, and selenate were the same or higher in rats fed 0.2 and $2 \mu \mathrm{g}$ Se/g diet as compared to rats fed the Se-deficient diet, suggesting a greater 


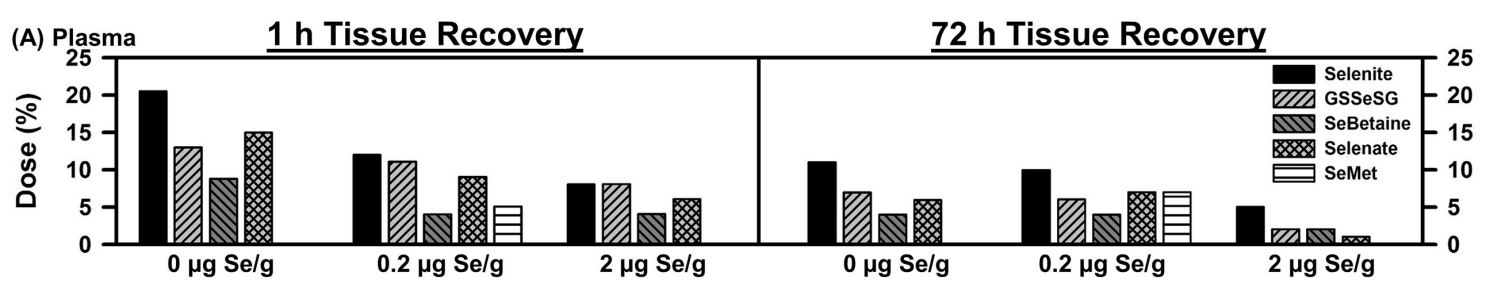

(B) Liver

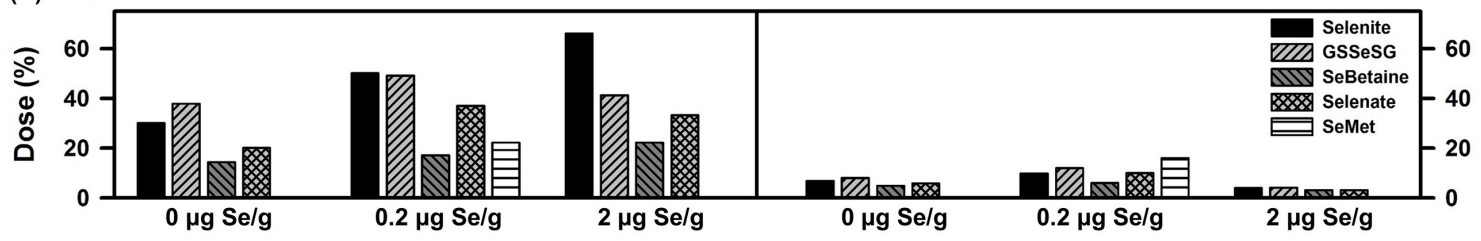

(C) Kidney
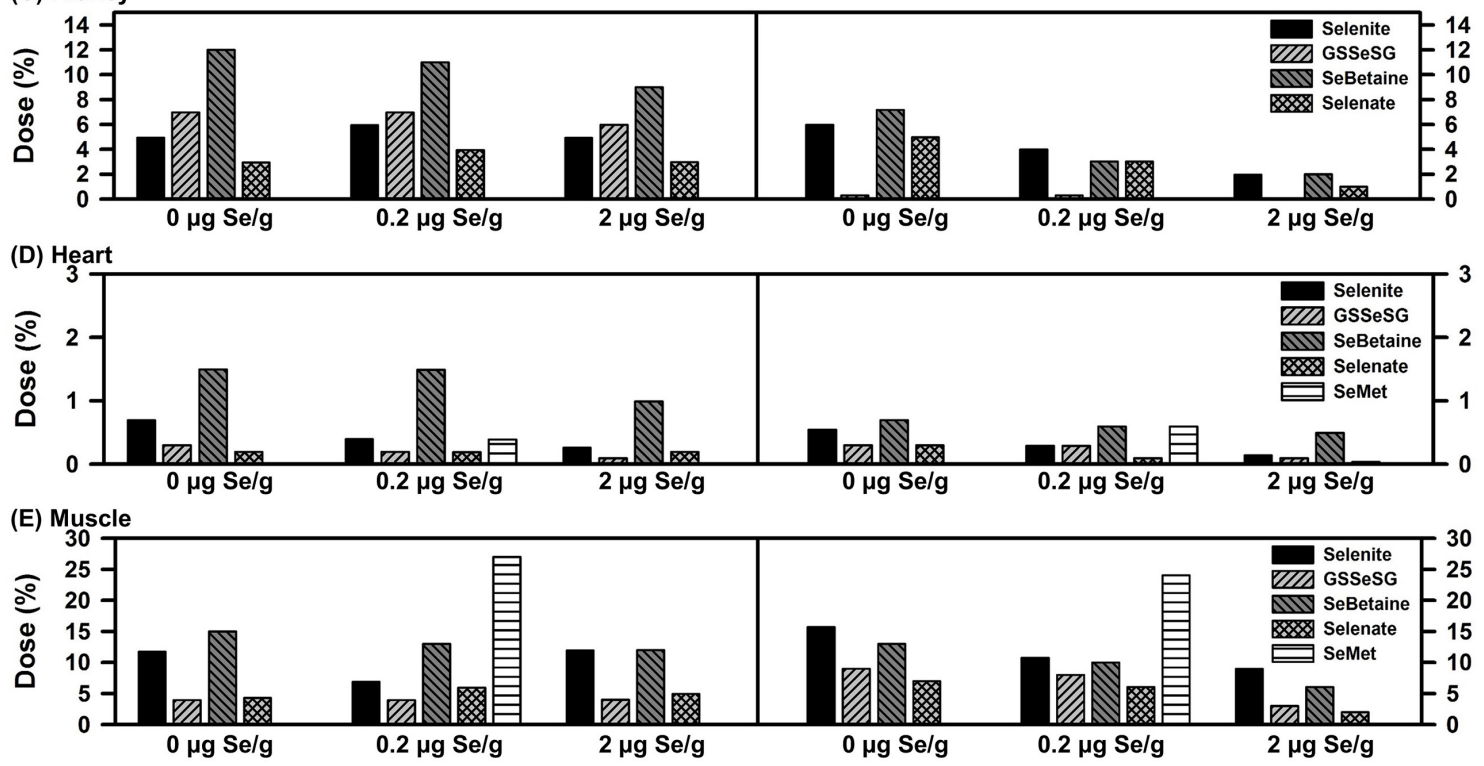

(F) Testes

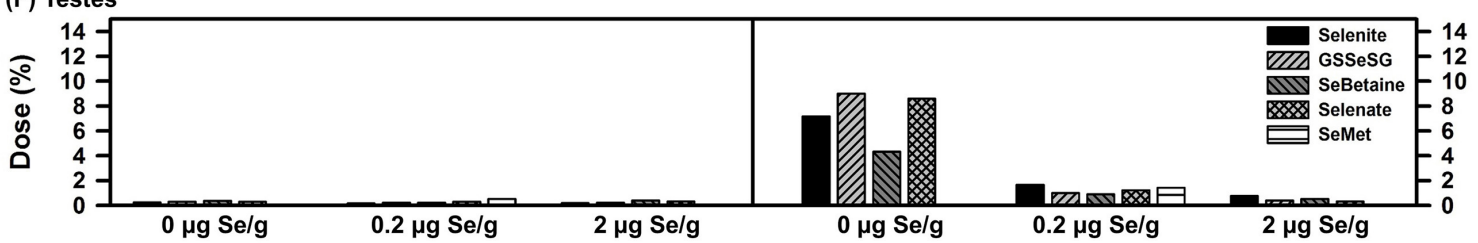

FIGURE 2 | Tissue ${ }^{75}$ Se recovery at 1 and $72 \mathrm{~h}$ after injection ${ }^{75}$ Se selenocompounds. Rats were treated as described for Figure 1. Values are the percent of the administered ${ }^{75}$ Se dose recovered in each tissue ( $n=1$ per treatment at each time for each selenocompound, $n=26$ total).

flux of ${ }^{75}$ Se to other tissues in Se-deficient rats. By $72 \mathrm{~h}$, recoveries were $4 \%$ or less in liver for all selenocompounds regardless of dietary Se; in rats fed $5 \mu \mathrm{g} \mathrm{Se} / \mathrm{g}$ as selenite, liver ${ }^{75} \mathrm{Se}$ recoveries were 59 and $3 \%$ at 1 and $72 \mathrm{~h}$, respectively, similar to levels in rats fed $2 \mu \mathrm{g} \mathrm{Se} / \mathrm{g}$ (data not shown). Overall, there was little effect of Se status on the recovery of ${ }^{75} \mathrm{Se}$ in liver.

Kidney, however, provided a third pattern. The level of dietary Se supplementation had little effect on recovery of ${ }^{75} \mathrm{Se}$ at $1 \mathrm{~h}$. Furthermore, the recovery of ${ }^{75} \mathrm{Se}$ at $1 \mathrm{~h}$ especially for SeBetaine but also GSSeSG was higher than for selenite, reflecting either targeted uptake by kidney, or reduced uptake/retention by liver and plasma. By $72 \mathrm{~h}$, there was little ${ }^{75}$ Se arising from GSSeSG found in kidney.

Heart also displayed higher retention of ${ }^{75} \mathrm{Se}$ from SeBetaine as compared to the other Se compounds at $1 \mathrm{~h}$. And relative to plasma, liver, and kidney, retention of ${ }^{75} \mathrm{Se}$ at $72 \mathrm{~h}$ in heart remained more similar to retention levels at $1 \mathrm{~h}$.

Recovery of ${ }^{75} \mathrm{Se}$ in muscle was calculated estimating that muscle was $40 \%$ of the total body weight of the rat (26). Recovery of ${ }^{75} \mathrm{Se}$ at $1 \mathrm{~h}$ and $72 \mathrm{~h}$ were almost identical for all Se compounds, and little affected by level of dietary Se. Even at $1 \mathrm{~h}$, SeMet ${ }^{75} \mathrm{Se}$ retention was 4 -times the level of selenite ${ }^{75} \mathrm{Se}$ retention 

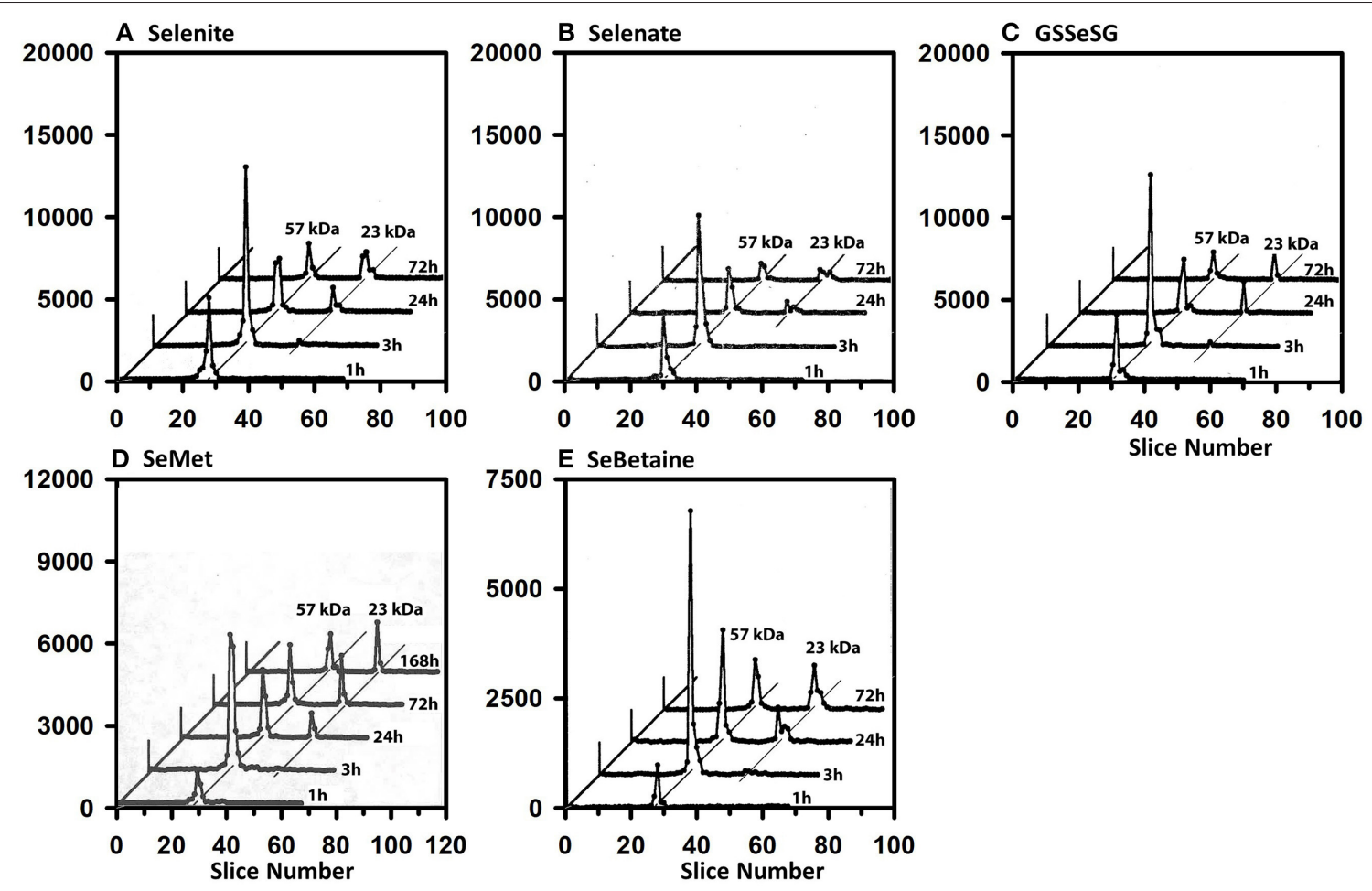

FIGURE 3 | Incorporation of ${ }^{75} \mathrm{Se}$ into plasma proteins. Rats were fed $0.2 \mu \mathrm{g} \mathrm{Se} / \mathrm{g}$ diet as selenite for $50-80 \mathrm{~d}$, injected iv with $50 \mu \mathrm{Ci}$ of tracer ${ }^{75} \mathrm{Se}-\mathrm{labeled} \mathrm{Selenite}$ (A), Selenate (B), GSSeSG (C), SeMet (D), and SeBetaine (E), and killed at 1, 3, 24, or $72 \mathrm{~h}$ (or $168 \mathrm{~h}$ for SeMet) afer dosing. Plasma samples (1,500 $\mu \mathrm{g}$ protein) were separated using gradient SDS/PAGE. Sample lanes in each gel were cut into 2 -mm slices and counted. The cpm for each slice are plotted to show ${ }^{75}$ Se incorporation into selenoproteins of different subunit molecular weights. Slice 1 contains polypeptides of the highest molecular weight. Plots for 3 , 24 , and $72 \mathrm{~h}$ were staggered, and diagonal lines are drawn through the major ${ }^{75}$ Se proteins to show the change in ${ }^{75}$ Se incorporation in these species with time. Each time profile in each

selenocompound panel is from one rat ( $n=21$ total rats). Plasma SELENOP is $57 \mathrm{kDa}$ and GPX3 is $23 \mathrm{kDa}$.

in rats fed $0.2 \mu \mathrm{g} \mathrm{Se/g.} \mathrm{This} \mathrm{distribution} \mathrm{clearly} \mathrm{shows} \mathrm{the}$ specific uptake and retention of SeMet relative to the other injected selenocompounds.

At $1 \mathrm{~h}$, there was almost no ${ }^{75} \mathrm{Se}$ found in testes regardless of the form of Se administered. By $72 \mathrm{~h}$, testes in Se-deficient rats retained $4-8 \%$ of the administered ${ }^{75} \mathrm{Se} .{ }^{75}$ Se retention was dramatically reduced in rats fed $0.2 \mu \mathrm{g} \mathrm{Se} / \mathrm{g}$ diet, and further reduced in rats fed $2 \mu \mathrm{g} \mathrm{Se} / \mathrm{g}$. In contrast to the other five tissues, injected ${ }^{75} \mathrm{Se}$ was targeted to testes in Se deficiency, but this targeted flux was curtailed in Se-adequate male rats.

\section{SDS/PAGE Analysis}

The use of the SDS/PAGE analysis of ${ }^{75} \mathrm{Se}$ incorporation into selenoproteins used 2-mercaptoethanol treatment to separate protein subunits according to MW, and to reduce "loosely bound Se from proteins." Mercaptoethanol treatment will also reduce selenodisulfide linkages, thus releasing low-MW Se forms bound to proteins through these links. Subsequent SDS/PAGE eluted resulting low-MW species into the bottom buffer so that the resulting profiles only display high-MW protein subunits containing Sec. Potentially also retained on the gel might be other high-MW proteins with $\mathrm{Se}-\mathrm{C}$ bonds, but this would not include Se species linked via selenodisulfide linkages such as selenosugars linked to protein cysteines. The result is the clean profiles of selenoproteins we reported in 1988 as compared to the gel filtration profiles, which showed 4 broad peaks, including $>250$ $\mathrm{kDa}$ species at the void volume, the $\sim 100 \mathrm{kDa}$ peak containing tetrameric GPX1, the $\sim 20 \mathrm{kDa}$ peak containing GPX4, and the largest peak containing low-MW species eluting at the column volume (26). Follow-up SDS/PAGE analysis of these individual peaks showed that the $100 \mathrm{kDa}$ peak contained $23 \mathrm{kDa}$ GPX1 subunits and the $20 \mathrm{kDa}$ peak contained GPX4 polypeptide; the $>250 \mathrm{kDa}$ and low-MW peaks contained no ${ }^{75} \mathrm{Se}$-labeled protein peaks after this 2-mercaptoethanol + SDS/PAGE analysis (39). These ${ }^{75} \mathrm{Se}$ species are the "missing" selenometabolites not detected in our use of SDS/PAGE to analyze for selenoproteins.

Full-length plasma SELENOP has a peptide MW of $43 \mathrm{kDa}$ but is glycosylated to have an apparent MW of $57 \mathrm{kDa}(40)$. Figure 3 shows the SDS/PAGE ${ }^{75}$ Se profile in plasma for the five selenocompounds at $1,3,24$, and $72 \mathrm{~h}$ after iv ${ }^{75}$ Se injection in rats fed $0.2 \mu \mathrm{g} \mathrm{Se} / \mathrm{g}$ as selenite. The profiles are all remarkably the same. Maximum incorporation into SELENOP is observed at $3 \mathrm{~h}$ as reported previously (40). Notable ${ }^{75} \mathrm{Se}$ incorporation into plasma GPX3 is not observed until $24 \mathrm{~h}$, and this level of incorporation remains at $72 \mathrm{~h}$. These profiles clearly indicate that 

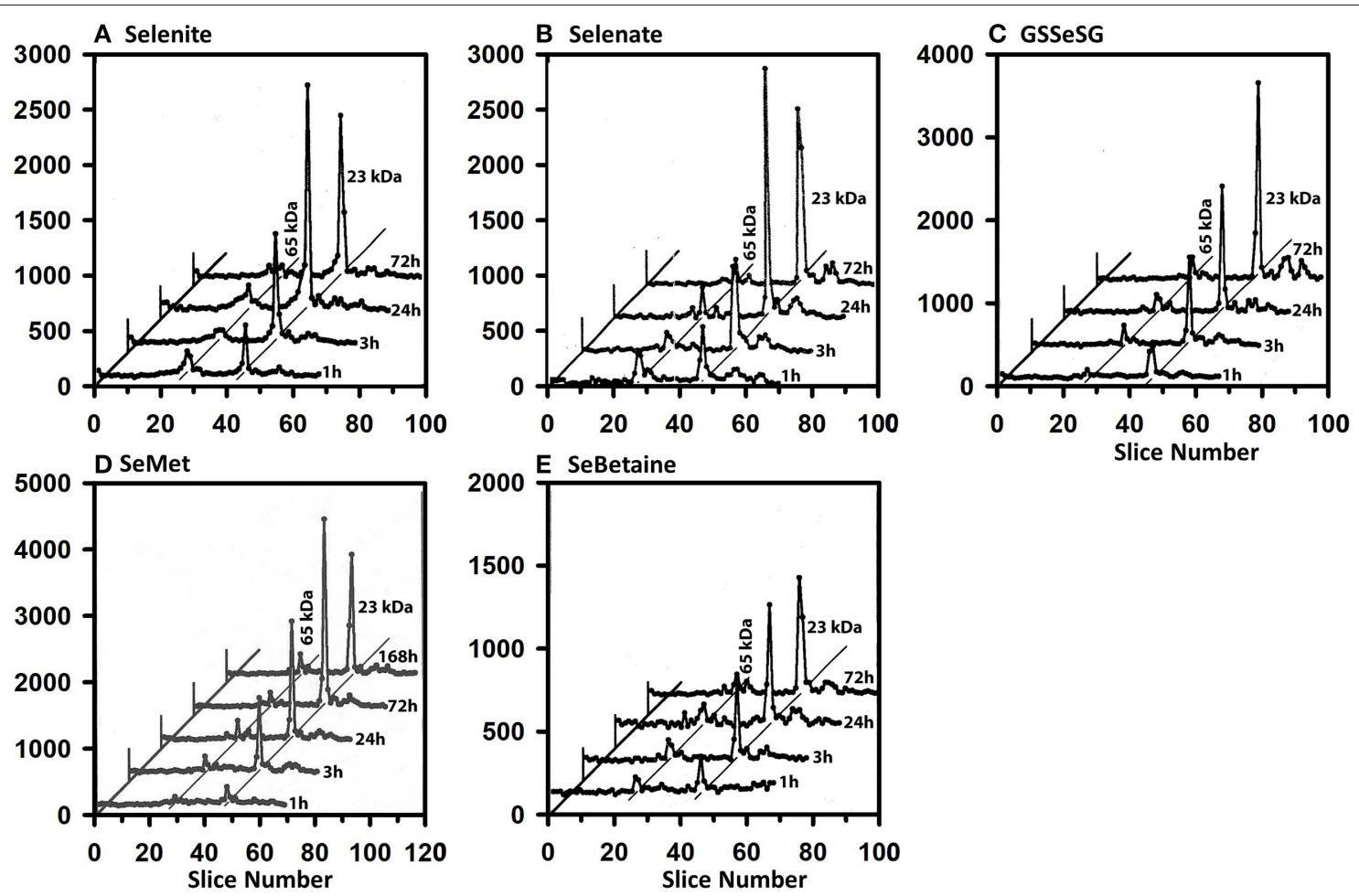

FIGURE 4 | Incorporation of ${ }^{75}$ Se into liver cytosolic proteins from Selenite (A), Selenate (B), GSSeSG (C), SeMet (D), and SeBetaine (E). Rats were treated as described for Figure 3. After homogenization and centrifugation at 105,000 $\mathrm{g} \times 60 \mathrm{~min}$, cytosols (1,500 $\mu \mathrm{g}$ protein) were separated using gradient SDS/PAGE as described for Figure 3 ( $n=21$ total rats). Liver GPX1 is $23 \mathrm{kDa}$, and the $65 \mathrm{kDa}$ species are likely to the isoenzymes of TXNRD1.

all five selenocompounds are rapidly metabolized to the common precursor used for incorporation into selenoproteins.

The ${ }^{75} \mathrm{Se}$ profiles in liver are also all remarkably the same for the five compounds (Figure 4). By $1 \mathrm{~h}$, substantial injected ${ }^{75} \mathrm{Se}$ was rapidly incorporated into the $23 \mathrm{kDa}$ GPX1 subunit, with maximal ${ }^{75}$ Se labeling with selenite and selenate at $24 \mathrm{~h}$. At $72 \mathrm{~h},{ }^{75} \mathrm{Se}$ incorporation into GPX1 from GSSeSG and SeMet was even higher than at $24 \mathrm{~h}$, suggesting these species were more slowly metabolized into the Se precursor than for selenite and selenate. The reduced uptake of ${ }^{75} \mathrm{Se}$ from SeBetaine into liver resulted in slower labeling of GPX1. In addition, several additional selenoprotein subunits of 65 and 19 $\mathrm{kDa}$ were also labeled, but at far lower levels than for GPX1. These species are likely to be cytosolic thioredoxin reductase 1 (TXNRD1) with isoforms at 63 and $55 \mathrm{kDa}$, and GPX4 at $19 \mathrm{kDa}$.

The ${ }^{75} \mathrm{Se}$ selenoprotein profiles of heart supernatant (Figure 5) are also very similar for all four selenocompounds. At 1 and $3 \mathrm{~h}$, the $65 \mathrm{kDa}$ species contained more ${ }^{75} \mathrm{Se}$ than in GPX1 subunits for selenite, GSSeSG, and SeMet. This labeling diminished somewhat by $24 \mathrm{~h}$ when GPX1 subunit gained prominence, but both species retained ${ }^{75}$ Se labeling at $72 \mathrm{~h}$.

The ${ }^{75}$ Se profiles of testes supernatant show a different story (Figure 6). Early on, the $65 \mathrm{kDa}$ species were labeled at $3 \mathrm{~h}$, but by $24 \mathrm{~h}$ the $17 \mathrm{kDa}$ GPX4 is equally ${ }^{75} \mathrm{Se}$-labeled from selenite,
GSSeSG, SeMet, and SeBetaine. The GPX4 was the dominate ${ }^{75}$ Se-labeled selenoprotein at $72 \mathrm{~h}$.

\section{Effect of Se Status on ${ }^{75}$ Se-Selenoprotein Labeling}

The same-sized $50 \mu \mathrm{Ci}$ tracer dose of ${ }^{75} \mathrm{Se}$ was injected at various times into rats fed Se-deficient $(0 \mu \mathrm{g} \mathrm{Se} / g$ diet $)$, Se-adequate (0.2 $\mu \mathrm{g} \mathrm{Se} / \mathrm{g} \mathrm{diet})$, and high Se $(2 \mu \mathrm{g} \mathrm{Se} / \mathrm{g}$ diet $)$ to study the impact of Se status on flux of ${ }^{75} \mathrm{Se}$ into liver selenoproteins (Figures 7A-C). In Se-deficient liver, there was little effect of time after dosing on incorporation into selenoproteins, in contrast to what was observed in Se-adequate rats (Figure 4). Furthermore, in Se-deficient rats, the amount of ${ }^{75} \mathrm{Se}$ labeling of GPX1 was the same as the labeling of TXNRD at all times (Figure 7A), whereas ${ }^{75} \mathrm{Se}$ labeling of GPX1 increased dramatically in Seadequate liver from 1 to 3 to $24 \mathrm{~h}$ after dosing (Figure $7 \mathbf{B}$ ). In high-Se rat liver, there was little incorporation of ${ }^{75} \mathrm{Se}$ into the $65 \mathrm{kDa}$ species; ${ }^{75} \mathrm{Se}$ incorporation into GPX1 was considerably less as compared to Se-adequate liver, with the more modest incorporation doubling from 3 to $24 \mathrm{~h}$, and doubling again from 24 to $72 \mathrm{~h}$. The pattern of ${ }^{75} \mathrm{Se}$ incorporation from $\left[{ }^{75} \mathrm{Se}\right]$ selenate (Figures 7D-F) was virtually the same as that observed with $\left[{ }^{75} \mathrm{Se}\right]$ selenite, showing that both selenocompounds are metabolized in intact rats at similar rates into the precursor used for Se incorporation into selenoproteins. 

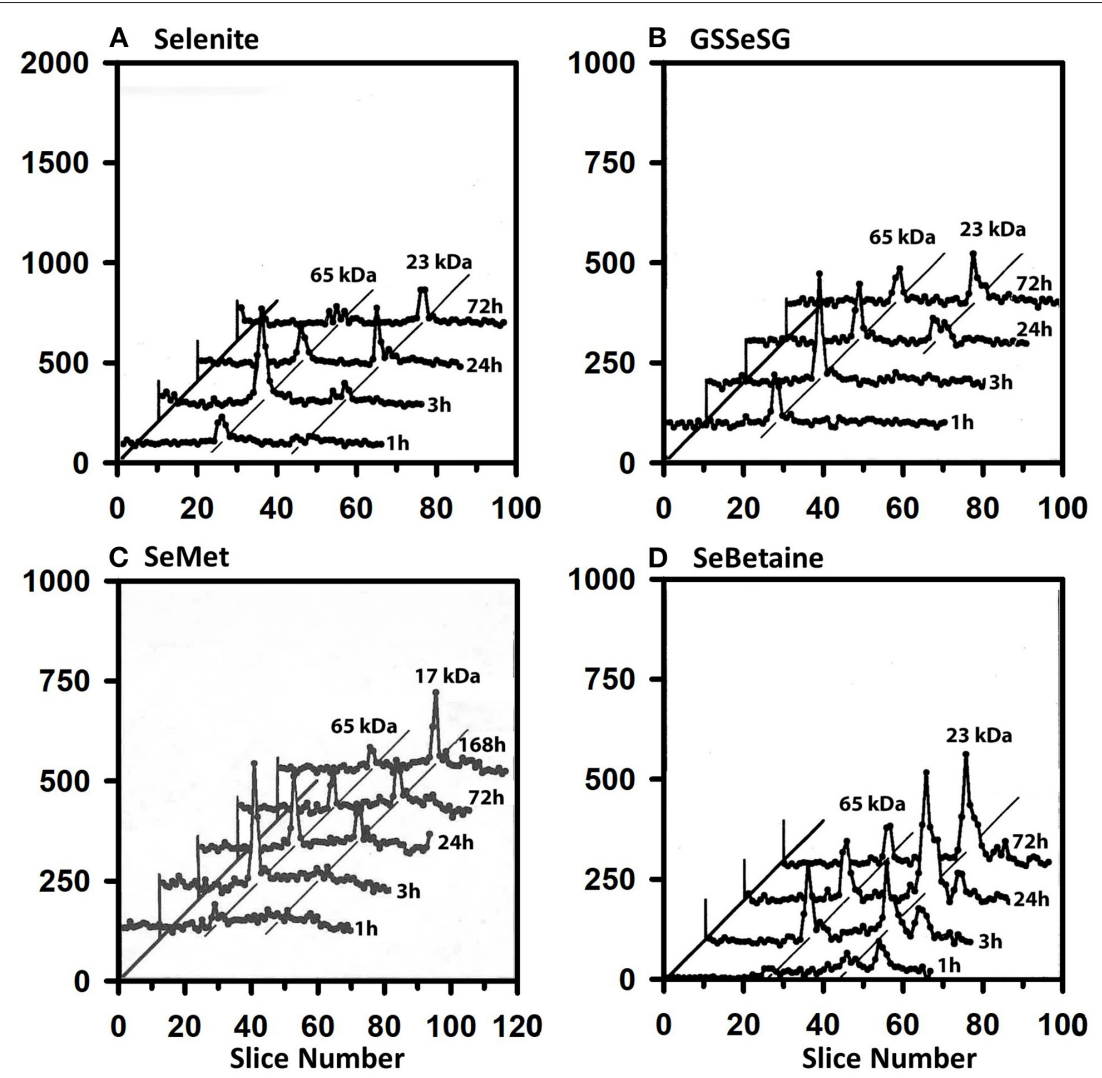

FIGURE 5 | Incorporation of ${ }^{75}$ Se into heart supernatant proteins from Selenite (A), GSSeSG (B), SeMet (C), and SeBetaine (D). Rats were treated as described for Figure 3. Heart tissue was homogenized in Tris/SDS and centrifuged at 105,000 x g, and supernatants (1,500 $\mu \mathrm{g}$ protein) were separated using gradient SDS/PAGE as described for Figure $\mathbf{3}$ ( $n=17$ total rats). GPX1 is $23 \mathrm{kDa}$, and the $65 \mathrm{kDa}$ species are likely to the isoenzymes of TXNRD.

\section{Effect of Met Status on ${ }^{75}$ Se-Selenoprotein Labeling From $\left[{ }^{75} \mathrm{Se}\right] \mathrm{SeMet}$}

Because SeMet mixes with the Met pool and is incorporated non-specifically as a Met analog into general body proteins $(16,17,19)$, we studied the effect of feeding three levels of dietary Met for $1 \mathrm{wk}$ in the Se-adequate diet $(0.2 \mu \mathrm{g} \mathrm{Se} / \mathrm{g}$ diet as selenite) prior to injection of $50 \mu \mathrm{Ci}$ of tracer $\left[{ }^{75} \mathrm{Se}\right] \mathrm{SeMet}$. Without Met supplementation, ${ }^{75} \mathrm{Se}$ incorporation into liver GPX1 from $\left[{ }^{75} \mathrm{Se}\right]$ SeMet was approximately half the level of incorporation from $\left[{ }^{75} \mathrm{Se}\right]$ selenite at all times in Se-adequate liver (Figures 8A-C). With $0.4 \%$ Met supplementation, the labeling of GPX1 from tracer $\left[{ }^{75} \mathrm{Se}\right]$ SeMet was similar to that from $\left[{ }^{75} \mathrm{Se}\right]$ selenite. Doubling dietary Met supplementation to $0.9 \%$ Met perhaps only slightly decreased the labeling of GPX1 relative to that observed with $0.4 \%$ dietary Met, suggesting that there was little enhanced release of ${ }^{75} \mathrm{Se}$ from $\left[{ }^{75} \mathrm{Se}\right]$ SeMet to the precursor form of Se used for selenoprotein synthesis, at least in liver.

In contrast to liver, a different pattern of ${ }^{75} \mathrm{Se}$ incorporation from $\left[{ }^{75} \mathrm{Se}\right]$ SeMet into plasma SELENOP was observed for the three levels of dietary Met (Figures 8D-F). The selenoprotein labeling patterns for SELENOP and GPX3 were virtually the same when Se-adequate rats were supplemented with 0 or $0.4 \%$ dietary Met for 1 week. Higher dietary Met supplementation at $0.9 \%$, however, doubled the ${ }^{75}$ Se labeling of plasma SELENOP at 3 and $24 \mathrm{~h}$, as compared to labeling in $0.4 \%$ Met rats, indicating that there was increase SeMet catabolism releasing ${ }^{75} \mathrm{Se}$ for incorporation into SELENOP.

\section{The "Missing" ${ }^{75} \mathrm{Se}$}

We used 2-mecaptoethanol treatment and SDS/PAGE analysis to focus on the flux of ${ }^{75} \mathrm{Se}$ into true selenoproteins, with the presumption that this would strip away low-MW selenometabolites and loosely bound selenospecies, including species linked by disulfide bonds. Our recent finding that lowMW and high-MW selenosugars are present in high quantities in Se-adequate and high-Se liver at least in turkeys (33), however, strongly suggests that the ${ }^{75}$ Se we did not find in the SDS/PAGE ${ }^{75}$ Se profiles is also important.

The recoveries of ${ }^{75} \mathrm{Se}$ in the gels following $\left[{ }^{75} \mathrm{Se}\right]$ selenite injection are shown in Figure 9 for rats fed 0 to $5 \mu \mathrm{g} \mathrm{Se} / \mathrm{g}$ as selenite. The major plasma selenoprotein (Figures 3, 8), SELENOP, is synthesized and secreted by the liver; the recovery of $>70 \%$ of the applied ${ }^{75} \mathrm{Se}$ in plasma as SELENOP at 1 and $3 \mathrm{~h}$ after injection agrees other reports (40). Similarly, recovery of $>50 \%$ of the injected ${ }^{75} \mathrm{Se}$ in the SDS/PAGE gels in testes supernatant, regardless of Se status, might be expected as 

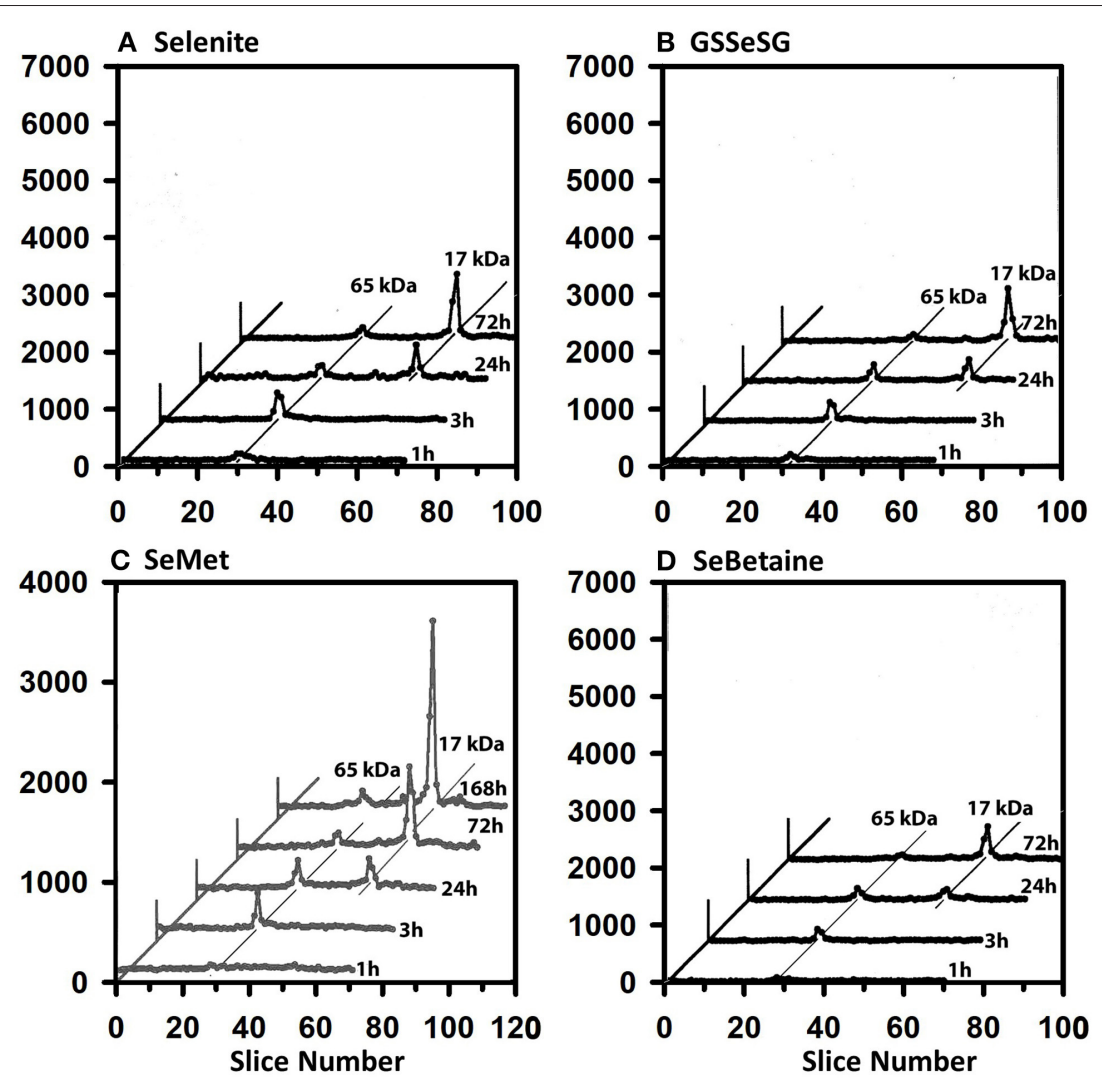

FIGURE 6 | Incorporation of ${ }^{75} \mathrm{Se}$ into testes supernatant proteins from Selenite (A), GSSeSG (B), SeMet (C), and SeBetaine (D). Rats were treated as described for Figure 3. Testes supernatants were prepared and analyzed by SDS/PAGE, as described for Figure $\mathbf{5}$ ( $n=17$ total rats). GPX4 is $17 \mathrm{kDa}$, and the $65 \mathrm{kDa}$ species are likely to the isoenzymes of TXNRD.

SELENOP is synthesized predominately by the liver, secreted, and then specifically targeted to the testes as mediated by the APOER2 receptor (LRP8) (41). In liver at $1 \mathrm{~h}$, however, $<15 \%$ of the applied ${ }^{75} \mathrm{Se}$ in liver cytosol was recovered on the gel as Seccontaining selenoproteins, regardless of Se status. At $3 \mathrm{~h}<40 \%$ was recovered in Se-deficient rat liver and $<20 \%$ in Se-adequate rat liver; this low recovery matches with the lack of ${ }^{75}$ Se labeling of liver GPX1 at 1 and $3 \mathrm{~h}$ (Figures 4, 7). Increasing Se status decreased the recovery ${ }^{75} \mathrm{Se}$ at both 1 and $3 \mathrm{~h}$, such that $<5 \%$ of the applied Se was recovered as Sec selenoproteins in liver cytosol from rats fed $5 \mu \mathrm{g} \mathrm{Se} / \mathrm{g}$. A similar effect of Se status was observed in kidney at 1 and $3 \mathrm{~h}$, although the ${ }^{75}$ Se recovered in kidney was double the recoveries observed in liver. By $24 \mathrm{~h}$ in both liver and kidney, $30-50 \%$ of the applied ${ }^{75}$ Se was recovered in the gels, consistent with the increased labeling of GPX1. Similar patterns were observed for tracer studies providing ${ }^{75} \mathrm{Se}$ as selenate or GSSeSG (data not shown). Clearly substantial cytosolic ${ }^{75}$ Se was present as species other than Sec in selenoproteins. Especially in liver, even at 24 and $72 \mathrm{~h}$, there was a progressive decline in ${ }^{75} \mathrm{Se}$ recovered as Sec selenoprotein as Se status increased from 0.2 to 2 to $5 \mu \mathrm{g} \mathrm{Se} / \mathrm{g}$ diet.

When tracer ${ }^{75} \mathrm{Se}$ was injected as SeMet, the patterns were very different (Figure 10), showing that the early fate of SeMet is decidedly different than for inorganic Se. At least $30 \%$ of the applied ${ }^{75} \mathrm{Se}$ was recovered in the gel, regardless of tissue. With increasing time, there appears to be increased recovery of ${ }^{75} \mathrm{Se}$ in as Sec in selenoproteins in liver and heart, but not in plasma. Feeding a marginal Met diet or doubling the diet Met, however, had little effect on incorporation of ${ }^{75} \mathrm{Se}$ from SeMet into protein as assessed by recovery upon SDS/PAGE analysis. This matches with the selenoprotein profiles shown in Figure 8, with little effect of level of dietary methionine on the ${ }^{75}$ Se labeling of GPX1 in liver and SELENOP in plasma.

\section{DISCUSSION}

These studies used only adult Holtzmann rats from our colony that were fed the basal Se-deficient diets supplemented with graded levels of Se as selenite for 50-80 days. The data for an individual selenocompound at each time in these figures was only collected for a single rat, so only the resulting patterns can be compared. No statistical analysis was conducted.

Collectively, the studies reported here present data from 80 individual rats. The SDS/PAGE profiles for these ${ }^{75} \mathrm{Se}$ tracer studies are very consistent and illustrate a constant timedriven pattern of ${ }^{75} \mathrm{Se}$ corporation into selenoproteins in four 

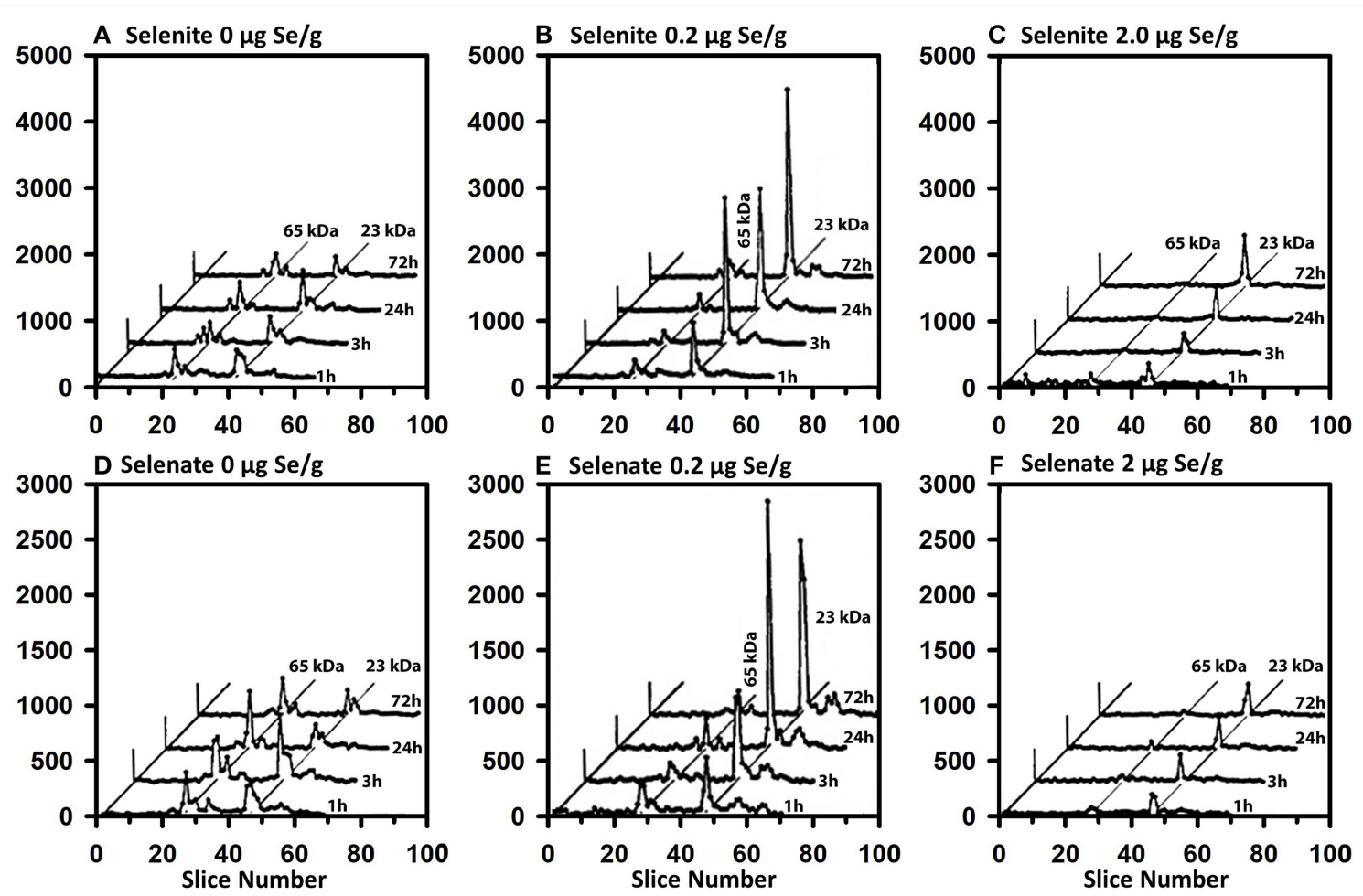

FIGURE 7 | Incorporation of ${ }^{75}$ Se from $\left[{ }^{75}\right.$ Se]selenite (A-C) and ${ }^{75}$ Se]selenate (D-F) into liver cytosolic proteins. Rats were fed the indicated dietary Se levels as selenite for $50-80 \mathrm{~d}$, injected iv with $50 \mu \mathrm{Ci}$ of tracer ${ }^{75}$ Se-labeled selenite or selenate, and killed at 1, 3, 24, or 72 h afer dosing. After homogenization and centrifugation at $105,000 \times$ g, cytosols ( $1,500 \mu \mathrm{g}$ protein) were separated using gradient SDS/PAGE as described for Figure 3 ( $n=24$ total rats). Liver GPX 1 is 23 $\mathrm{kDa}$, and the $65 \mathrm{kDa}$ species are similar to the isoenzymes of TXNRD1.

tissues. The overall result is a clear pattern of very rapid Se metabolism from a diverse set of selenocompounds to a common intermediate used for synthesis and incorporation into well-defined ${ }^{75} \mathrm{Se}$ selenoprotein patterns for at least the major selenoproteins: plasma SELENOP and GPX3, liver and heart GPX1 and the $65 \mathrm{kDa}$ species (most likely TXNRD1), and testes GPX4. No selenocompound resulted in incorporation into a profoundly different set of at least these major selenoproteins. Even SeBetaine, which had been identified as having distinct activity to prevent DMBA-induced mammary tumors, resulted in these same patterns. SeMet was similarly rapidly metabolized to the precursor used for selenoprotein synthesis. Collectively, these studies emphasize that this wide variety of selenocompounds are not uniquely or preferentially metabolized to provide Se for selenoprotein incorporation.

A schematic diagram of the metabolism of the five selenocompounds in these experiments is shown in Figure 11. All five ${ }^{75} \mathrm{Se}$ tracers were readily and rapidly metabolized to the selenide-level precursor used for co-translational incorporation of $\mathrm{Se}$ as $\mathrm{Sec}$ into selenoproteins (1-6). The various pathways shown in Figure $\mathbf{1 1}$ have been discussed in detail previously $(1,3,7,20)$, with this same selenidelevel selenospecies, the precursor for selenosugar synthesis $(32,33)$. The missing ${ }^{75} \mathrm{Se}$ metabolites, not detected by SDS/PAGE as selenoproteins, include low-MW selenosugars,
high-MW “selenosugar-decorated” proteins, and other unknown metabolites $(32,33)$.

These studies used tracer levels of ${ }^{75} \mathrm{Se}$. Estimates of total body burden of Se in an Se-adequate rat range from 48 to $61 \mu \mathrm{g}$ total Se fed selenite $(7,42)$. Rats of this age consume $\sim 30 \mathrm{~g} \mathrm{diet} / \mathrm{d}$, so feeding $0.2 \mu \mathrm{g} \mathrm{Se} / \mathrm{g}$ diet would provide $\sim 6 \mu \mathrm{g}$ of oral Se per day. A single injection of $\sim 0.5 \mu \mathrm{g}$ Se in rats fed $0.2 \mu \mathrm{g} \mathrm{Se} / \mathrm{g}$ diet represents $\sim 10 \%$ of the daily Se intake and $\sim 1 \%$ of the total body burden of Se, and thus can be considered a tracer. In Se-deficient rats fed the $0.02 \mu \mathrm{g} \mathrm{Se} / \mathrm{g}$ diet or $\sim 0.6 \mu \mathrm{g}$ per day, the $0.5 \mu \mathrm{g} \mathrm{Se}$ injection may represent an amount equivalent to that consumed in the diet. In a study with rats fed the Se-deficient diet for 60 $\mathrm{d}$, injection of $15 \mu \mathrm{g}$ Se as selenite failed to significantly raise GPX1 activity after $24 \mathrm{~h}(43)$. Here, the failure of the tracer ${ }^{75} \mathrm{Se}$ injections to increase ${ }^{75} \mathrm{Se}$ incorporation into GPX1 suggests the $0.5 \mu \mathrm{g}$ Se dose was insufficient to substantially raise liver Gpx1 mRNA levels (Figure 7), further indicating that these were ${ }^{75} \mathrm{Se}$ tracer studies even in Se-deficient rats.

It is thought that selenide or a GSH-selenide intermediate are the precursor species used in the first step in Sec synthesis $(3,6)$. These studies show that both the inorganic and the organic selenocompounds were rapidly metabolized to the Secsynthesis precursor. Furthermore, the pattern and timing of ${ }^{75} \mathrm{Se}$ labeling were almost identical in each tissue for all the selenocompounds. There was no apparent unique metabolism of 

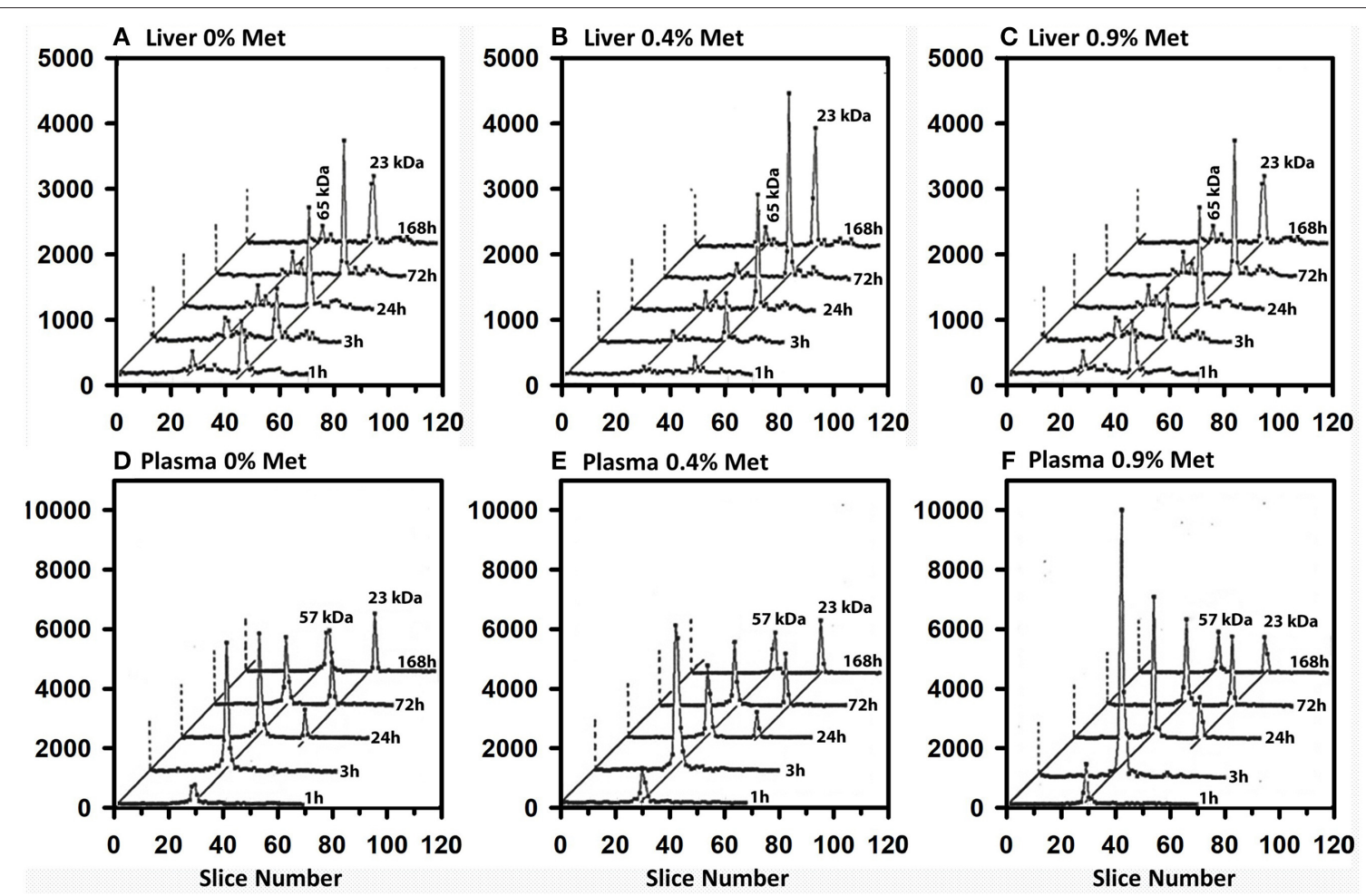

FIGURE 8 | Incorporation of ${ }^{75}$ Se from $\left[{ }^{75}\right.$ Se]SeMet into liver cytosolic (A-C) and plasma (D-F) proteins. Rats were supplemented with $0.2 \mu \mathrm{g}$ Se/g diet as selenite in the basal diet containing $0.4 \%$ supplemental Met for 50-80 d. For 7 days prior to Se injection, supplemental Met was adjusted to 0, 0.4 or 0.9\% D,L-Met; rats were then injected iv with $50 \mu \mathrm{Ci}$ of tracer ${ }^{75} \mathrm{Se}$-labeled SeMet, and killed at 1, 3, 24, 72, or $168 \mathrm{~h}$ afer dosing. Liver cytosol and plasma samples were prepared as described in Figures $\mathbf{3}$ and $\mathbf{4}$ ( $n=30$ total rats). Liver GPX1 is $23 \mathrm{kDa}$, and the $65 \mathrm{kDa}$ species are similar to the isoenzymes of TXNRD1; plasma SELENOP is $57 \mathrm{kDa}$ and GPX3 is $23 \mathrm{kDa}$.

one of these selenocompounds relative to the others, indicating that once internalized, the systemic Se metabolism of these species is the same. Furthermore, the similar timing for Se incorporation from these species indicates that the rate-limiting steps in selenoproteins synthesis occur after uptake and initial metabolism and are not associated with the differences in initial metabolism.

Today's understanding of selenoprotein expression and regulation can explain the observed ${ }^{75} \mathrm{Se}$ labeling patterns. When tracer $\left[{ }^{75} \mathrm{Se}\right]$ selenite and $\left[{ }^{75} \mathrm{Se}\right]$ selenate were injected into Se-deficient rats, Se deficiency dramatically decreased the labeling of GPX1 in liver relative to Se-adequate rats at 3 to $72 \mathrm{~h}$ after injection, but had little effect on labeling of the 65 $\mathrm{kDa}$ species. We now know that liver Gpx1 transcripts are dramatically reduced in liver by Se deficiency to $10 \%$ of Seadequate levels $(35,38,44)$, providing an explanation for the blunting of ${ }^{75} \mathrm{Se}$ incorporation into GPX1 in Se-deficient rats. Se repletion studies show that it takes $24 \mathrm{~h}$ to substantially raise liver GPX1 activity (43), further explaining the observed delay to $24 \mathrm{~h}$ in achieving the maximal ${ }^{75} \mathrm{Se}$ incorporation into liver GPX1 (Figure 4). The failure to see increased ${ }^{75} \mathrm{Se}$ incorporation into Se-deficient liver (Figures 7A,D) further shows that the administered ${ }^{75} \mathrm{Se}$ was as a tracer dose which did not substantially raise total Se status. High Se status $(2 \mu \mathrm{g}$
Se/g) markedly diminished the ${ }^{75}$ Se labeling of both GPX1 and the $65 \mathrm{kDa}$ species, illustrating additional dilution of the tracer ${ }^{75} \mathrm{Se}$ (Figures 7C,F).

Our studies in this rat model show that more than half of the selenoprotein transcripts are not significantly decreased by Se deficiency; Txnrd1 mRNAs are only decreased to $60 \%$ of Se-adequate levels (35), This can explain why sustained ${ }^{75} \mathrm{Se}$ incorporation into the $65 \mathrm{kDa}$ species was observed starting at $1 \mathrm{~h}$ in Se-deficient rat liver. Similarly, transcripts for liver SELENOP liver are not decreased in Se deficiency, explaining the rapid labeling of plasma SELENOP by $3 \mathrm{~h}$ (Figure 3). Gpx3 transcripts in kidney are also non-significantly decreased only to $60 \%$ of Se-adequate levels (35), supporting the appearance of ${ }^{75} \mathrm{Se}$ labeled GPX3 in plasma at $24 \mathrm{~h}$. Thus, the subsequent research on selenoprotein expression and regulation of selenoprotein transcripts since these tracer studies were conducted provides supporting rationale and insight into observed patterns of ${ }^{75} \mathrm{Se}$ incorporation into selenoproteins.

Basic biochemical studies have shown that SeMet is readily acylated to Met-tRNA and is incorporated into proteins in place of Met (19). Nutritional studies have further shown that marginal dietary Met increases deposition of SeMet into body proteins and decreases release of Se for tissue GPX1 synthesis (17). In the present studies, feeding a marginal-Met vs. Met-adequate diet 


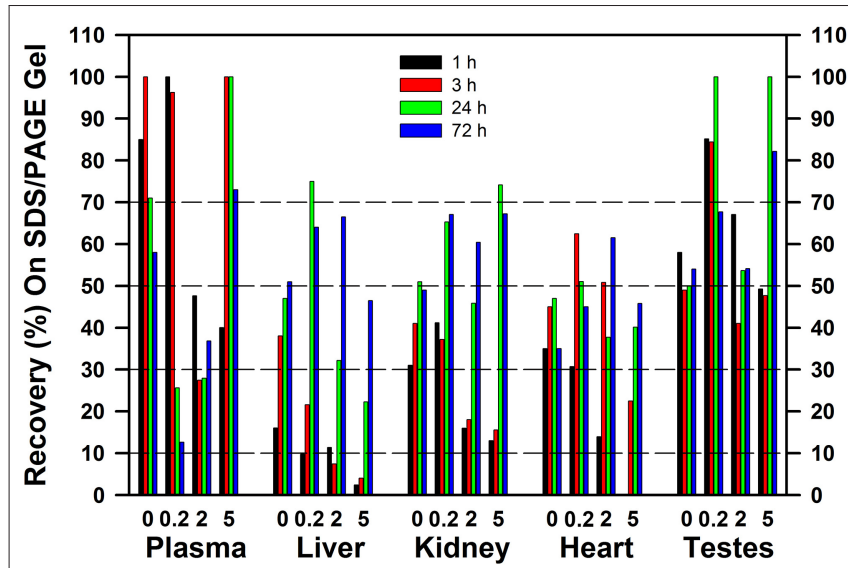

FIGURE 9 | Recovery of ${ }^{75} \mathrm{Se}$ from $\left[{ }^{75} \mathrm{Se}\right]$ selenite as ${ }^{75} \mathrm{Se}$-labeled

selenoproteins on SDS/PAGE gels. Rats were supplemented with $0,0.2,2$, or $5 \mu \mathrm{g} \mathrm{Se} / \mathrm{g}$ diet as selenite for $50-80 \mathrm{~d}$, injected iv with $50 \mu \mathrm{Ci}$ of $\left[{ }^{75}\right.$ Se]selenite, and were tissues subjected to SDS/PAGE as described for Figures 2-6 $(n=$ 16 total rats). Values are the percent of the applied ${ }^{75}$ Se recovered in the gel after SDS/PAGE in the indicated tissues at the indicated times.

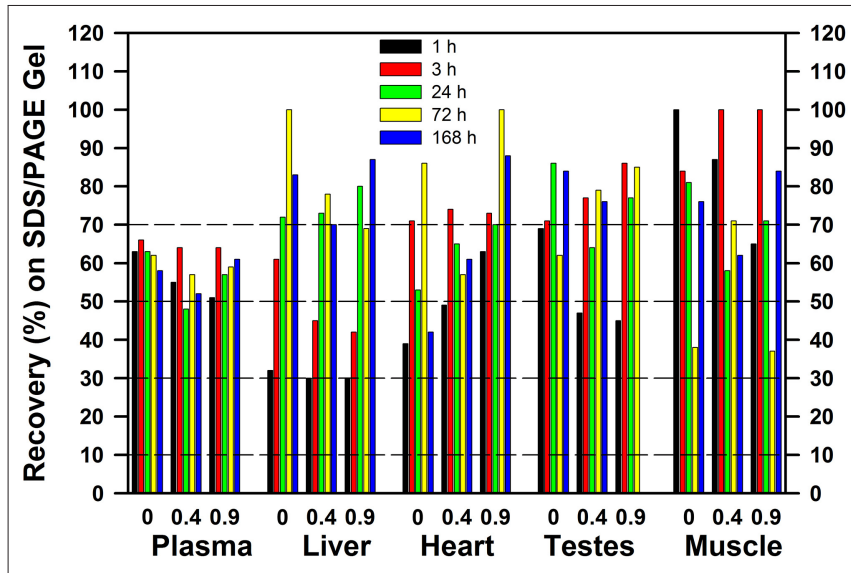

FIGURE 10 | Recovery of ${ }^{75} \mathrm{Se}$ from $\left[{ }^{75} \mathrm{Se}\right] \mathrm{SeMet}$ as ${ }^{75} \mathrm{Se}$-labeled selenoproteins on SDS/PAGE gels. Rats were supplemented with $0.2 \mu \mathrm{g} \mathrm{Se} / \mathrm{g}$ diet as selenite in the basal diet containing $0.4 \%$ supplemental Met for $50-80$ d. For 7 days prior to Se injection, supplemental Met was adjusted to $0,0.4$, or $0.9 \% \mathrm{D}, \mathrm{L}-\mathrm{Met}$; rats were then injected iv with $50 \mu \mathrm{Ci}$ of $\left[{ }^{75} \mathrm{Se}\right] \mathrm{SeMet}$, and tissues were subjected to SDS/PAGE as described for Figures 2-6 $(n=15$ total rats). Values are the percent of the applied ${ }^{75} \mathrm{Se}$ recovered in the gel after SDS/PAGE in the indicated tissues at the indicated times.

for $1 \mathrm{wk}$ prior to tracer $\left[{ }^{75} \mathrm{Se}\right] \mathrm{SeMet}$ injection had minimal effect of labeling of plasma SELENOP or GPX3, which indicated there was sufficient SeMet degradation to maintain the flux of Se into these species in Se-adequate rats. Similarly, high Met feeding for $1 \mathrm{wk}$ also exerted at most small changes on SELENOP and GPX3 labeling. In liver in contrast, feeding a marginal Met diet for $1 \mathrm{wk}$ prior to ${ }^{75}$ Se injection increased labeling of liver GPX1, suggesting increased catabolism of SeMet to the Se precursor used for selenoprotein synthesis; high Met feeding for $1 \mathrm{wk}$ had little effect on labeling of liver GPX1, perhaps because additional Se was incorporated into plasma SELENOP. Overall, feeding

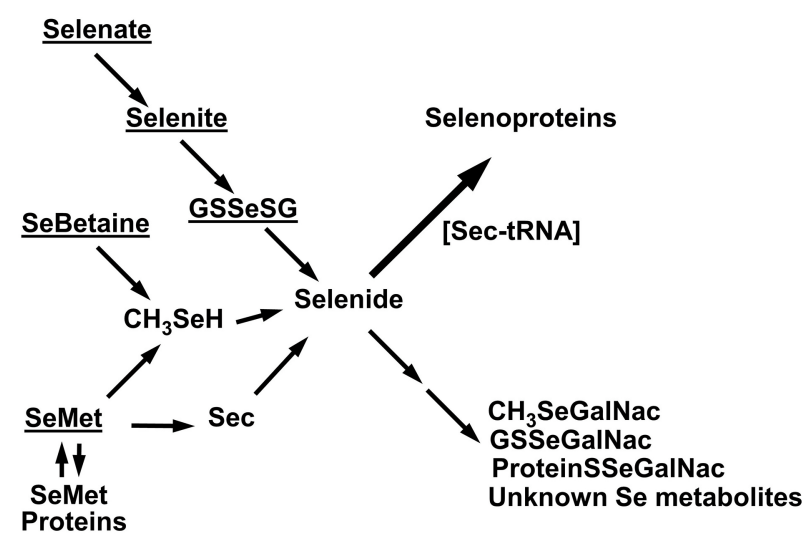

FIGURE 11 | Schematic diagram of Se metabolism to selenoproteins. Underlined are the five tracer selenocompounds administered in these experiments. Selenate is reduced to selenite; selenite can react with GSH to form GSSeSG, which is then further reduced to selenide. SeMet is degraded via transulfuration to Sec which can be metabolized to selenide, or SeMet is degraded via transamination to methaneselenol and then selenide.

Alternatively, SeMet can be incorporated into general body proteins as a methionine analog. SeBetaine is degraded to release methaneselenol.

Selenide is the precursor used for selenoprotein incorporation, as assessed by SDS/PAGE in these studies. Metabolites not detected by SDS/PAGE include the low MW selenosugars, high-MW "selenosugar-decorated" proteins, and other unknown metabolites.

these varied Met diets to older rats for just 1 week did not have as dramatic effects as was found in longer non-tracer studies in young rats, or in studies on utilization of stored SeMet in general body tissues to provide Se for GPX1 synthesis $(13,16,17)$.

The hidden story in these experiments is the extent of loss of ${ }^{75} \mathrm{Se}$ when tissue extracts were subjected to 2-mercaptoethanol treatment followed by SDS/PAGE. In liver and kidney at 1 and $3 \mathrm{~h}$ after ${ }^{75} \mathrm{Se}$ injection, especially in rats fed $0.2,2$, and $5 \mu \mathrm{g}$ $\mathrm{Se} / \mathrm{g}$, there was an increasingly small amount of the cytosolic ${ }^{75} \mathrm{Se}$ detected as selenoprotein ${ }^{75} \mathrm{Se}$; in rats fed $5 \mu \mathrm{g} \mathrm{Se} / \mathrm{g}$ at 1 and $3 \mathrm{~h},<5 \%$ of liver cytosolic ${ }^{75} \mathrm{Se}$ and $<20 \%$ of kidney cytosolic ${ }^{75}$ Se was present in the selenoproteins retained in the SDS/PAGE gels. When these studies were conducted, we presumed that the missing ${ }^{75} \mathrm{Se}$ was low-MW intermediates on the pathways to selenoprotein incorporation or to formation of methylated excretion products (26). With our recent finding that more Se is present as selenosugars than is present as Sec even in Seadequate turkey liver (33), the implication is that the missing ${ }^{75} \mathrm{Se}$ in these rat studies may have initially been selenosugars linked via selenodisulfide linkages nonspecifically to cysteine residues in high-MW general proteins. These species would be released by the 2 -mercaptoethanol treatment and swept off at the bottom of the gel. Similarly, low MW selenosugar species such as $\mathrm{CH}_{3}$ SeGalNac and GS-SeGalNac would be released as well. In rats fed 2 or $5 \mu \mathrm{g} \mathrm{Se} / \mathrm{g}$ vs. $0.2 \mu \mathrm{g} \mathrm{Se} / \mathrm{g}$, there was even more missing ${ }^{75} \mathrm{Se}$ in rats, suggesting that increased quantities of these species are present in rat liver and kidney cytosols. The levels of these species in microsomal, mitochondrial, and nuclear fractions are completely unknown at present, as the turkey liver studies were 
done on extracts of frozen tissue that would have included all subcellular organelles. Lastly, the increased retention of ${ }^{75} \mathrm{Se}$ in the gels at 24 and $72 \mathrm{~h}$ in liver and kidney, vs. 1 and $3 \mathrm{~h}$, suggests that there may be rapid flux or turnover of Se within these missing, hypothetical, selenosugar pools of Se.

Low-MW selenosugars have been identified in animal tissues by multiple investigators, but they were always reported as being found in low-MW fractions. The discoverers of $\mathrm{CH}_{3}$-SeGalNac in urine also reported separation of liver cytosol into a highMW protein-containing fraction and a low-MW fraction by ultrafiltration, but reported $\mathrm{CH}_{3}-\mathrm{SeGalNac}$ only in the lowMW fraction $(32,45)$. Other researchers used HPLC as the first step for plasma and tissue cytosol analysis and found lateeluting low-MW species that were identified as $\mathrm{CH}_{3}$-SeGalNac and GSH-SeGalNac. These researchers also found broad earlyeluting HPLC peaks that were described as containing highMW selenoproteins/Se-binding proteins, but none of these reports recognized that the high-MW protein fractions could also contain selenosugars (46-49). Takahashi and colleagues (50) used stable isotope mass spectroscopy to identify GSH-SeGalNac and $\mathrm{CH}_{3}$-SeGalNac in serum, liver, and kidney in Se-deficient rats given non-tracer doses of nine different selenocompounds, but they also showed uncharacterized broad high-MW Se-containing protein peaks in the HPLC profiles (50). Thus, the high-MW selenosugar-decorated proteins in turkey liver appears to be the first characterization of what might be missing in our SDS/PAGE gel profiles of rat selenoproteins.

\section{CONCLUSIONS}

In summary, these studies show that there is very rapid Se metabolism from a diverse set of selenocompounds to the common intermediate used for synthesis and incorporation of ${ }^{75} \mathrm{Se}$ into the major selenoproteins in a variety of tissues. Collectively, these studies emphasize that this wide variety of selenocompounds are not uniquely or preferentially metabolized to provide Se for selenoprotein incorporation. Furthermore, examination of the SDS/PAGE selenoprotein profiles shows that

\section{REFERENCES}

1. Sunde RA, Hoekstra WG. Incorporation of selenium from selenite and selenocystine into glutathione peroxidase in the isolated perfused rat liver. Biochem Biophys Res Commun. (1980) 93:1181-8. doi: 10.1016/0006-291X(80)90614-2

2. Hatfield D, Diamond AM, Dudock B. Opal suppressor serine tRNA from bovine liver forms phosphoseryl- tRNA. Proc Natl Acad Sci USA. (1982) 79:6215-9. doi: 10.1073/pnas.79.20.6215

3. Sunde RA, Evenson JK. Serine incorporation into the selenocysteine moiety of glutathione peroxidase. J Biol Chem. (1987) 262:9337. doi: 10.1016/S0021-9258(19)75875-X

4. Chambers I, Frampton J, Goldfarb PS, Affara N, McBain W, Harrison $\mathrm{PR}$. The structure of the mouse glutathione peroxidase gene: the selenocysteine in the active site is encoded by the "termination" codon, TGA. EMBO J. (1986) 5:1221-7. doi: 10.1002/j.1460-2075.1986.tb0 4350.x synthesis of selenoproteins is only part of the full Se metabolism story. The missing ${ }^{75} \mathrm{Se}$ species, especially at early timepoints, are likely to be low-MW and high-MW selenosugars and related precursors. Differential metabolism of various selenocompounds into different selenosugar species may occur; these species may be involved in the prevention of cancer or other diseases linked to Se status and may be associated with Se toxicity. Studies similar to these presented here, and characterization of the Se species in tissues by HPLC-MS, will be needed to more fully flesh out the complete metabolism of selenium.

\section{DATA AVAILABILITY STATEMENT}

The original contributions presented in the study are included in the article/supplementary material, further inquiries can be directed to the corresponding authors.

\section{ETHICS STATEMENT}

The animal study was reviewed and approved by Animal Care and Use Committee, University of Arizona (A3248 \#86-0172 and \#86-0357) Animal Care and Use Committee, University of Missouri (A3394 \#1425).

\section{AUTHOR CONTRIBUTIONS}

All authors listed have made a substantial, direct and intellectual contribution to the work, and approved it for publication.

\section{FUNDING}

This research was supported in part by The National Institutes of Health, grants DK32942, CA45164, and DK43491, by the National Institute of Food and Agriculture, United States Department of Agriculture, Hatch project 1004389, and by the Wisconsin Alumni Foundation Selenium Nutrition Research Fund No. 12046295.
5. Berry MJ, Banu L, Chen Y, Mandel SJ, Kieffer JD, Harney JW, et al. Recognition of a UGA as a selenocysteine codon in Type I deiodinase requires sequences in the 3' untranslated region. Nature. (1991) 353:273-6. doi: 10.1038/353273a0

6. Labunskyy VM, Hatfield DL, Gladyshev VN. Selenoproteins: molecular pathways and physiological roles. Physiol Rev. (2014) 94:739-77. doi: 10.1152/physrev.00039.2013

7. Sunde RA. Molecular biology of selenoproteins. Annu Rev Nutr. (1990) 10:451-74. doi: 10.1146/annurev.nu.10.070190.002315

8. Kryukov GV, Castellano S, Novoselov SV, Lobanov AV, Zehtab O, Guigo $\mathrm{R}$, et al. Characterization of mammalian selenoproteomes. Science. (2003) 300:1439-43. doi: 10.1126/science. 1083516

9. Gladyshev VN, Arner ES, Berry MJ, Brigelius-Flohe R., Bruford E. A., Burk R. F. et al. Selenoprotein gene nomenclature. J Biol Chem. (2016) 291:2403640. doi: 10.1074/jbc.M116.756155

10. Thomson CD. Assessment of requirements for selenium adequacy of selenium status: a review. Eur J Clin Nutr. (2004) 58:391402. doi: 10.1038/sj.ejcn. 1601800 
11. Ip C, Dong Y, Ganther HE. New concepts in selenium chemoprevention. Cancer Meta Rev. (2002) 21:281-9. doi: 10.1023/A:10212630 27659

12. Rayman MP. Selenium and human health. Lancet. (2012) 379:125668. doi: 10.1016/S0140-6736(11)61452-9

13. Sunde RA, Gutzke GE, Hoekstra WG. Effect of dietary methionine on the biopotency of selenite and selenomethionine in the rat. J Nutr. (1981) 111:7686. doi: $10.1093 / \mathrm{jn} / 111.1 .76$

14. Ip C, White G. Mammary cancer chemoprevention by inorganic and organic selenium: single agent treatment or in combination with vitamin $\mathrm{E}$ and their effects on in vitro immune functions. Carcinogenesis. (1987) 8:17636. doi: $10.1093 / \mathrm{carcin} / 8.12 .1763$

15. Xia YM, Hill KE, Li P, Xu J, Zhou D, Motley AK, et al. Optimization of selenoprotein $\mathrm{P}$ and other plasma selenium biomarkers for assessment of the selenium nutritional requirement. A placebo-controlled double-blind study of selenomethionine supplementation in selenium-deficient chinese subjects. Am J Clin Nutr. (2010) 92:525-31. doi: 10.3945/ajcn.2010.29642

16. Waschulewski IH, Sunde RA. Effect of dietary methionine on the utilization of tissue selenium from dietary selenomethionine for glutathione peroxidase in the rat. J Nutr. (1988) 118:367-74. doi: 10.1093/jn/118.3.367

17. Waschulewski IH, Sunde RA. Effect of dietary methionine on tissue selenium glutathione peroxidase activity in rats fed selenomethionine. Br J Nutr. (1988) 60:57-68. doi: 10.1079/BJN19880076

18. Ip C. Differential effect of dietary methionine on the biopotency of selenomethionine and selenite in cancer chemoprevention. J Natl Cancer Inst. (1988) 80:258-62. doi: 10.1093/jnci/80.4.258

19. McConnell KP, Hoffman JL. Methionine-selenomethionine parallels in rat liver polypeptide chain synthesis. FEBS Lett. (1972) 24:60-2. doi: 10.1016/0014-5793(72)80826-3

20. Ip C, Ganther HE. Activity of methylated forms of selenium in cancer prevention. Cancer Res. (1990) 50:1206-11.

21. Wilber CG. Toxicology of selenium: a review. Clin Toxicol. (1980) 17:171230. doi: $10.3109 / 15563658008985076$

22. Yang GQ, Wang S, Zhou R, Sun S. Endemic selenium intoxication of humans in China. Am J Clin Nutr. (1983) 37:872-81. doi: 10.1093/ajcn/37.5.872

23. MacFarquhar JK, Broussard DL, Melstrom P, Hutchinson R, Wolkin A, Martin C, et al. Acute selenium toxicity associated with a dietary supplement. Arch Intern Med. (2010) 170:256-61. doi: 10.1001/archinternmed.2009.495

24. Sunde RA, Li JL., Taylor RM. Insights for setting of nutrient requirements, gleaned by comparison of selenium status biomarkers in turkeys and chickens versus rats, mice, and lambs. Adv Nutr. (2016) 7:1129-38. doi: 10.3945/an.116.012872

25. Sunde RA. Gene set enrichment analysis of selenium-deficient high-selenium rat liver transcript expression comparison with turkey liver expression. J Nutr. (2021) 151:772-84. doi: 10.1093/jn/nxaa333

26. Evenson JK, Sunde RA. Selenium incorporation into selenoproteins in the Se-adequate and Se-deficient rat. Proc Soc Exp Biol Med. (1988) 187:16980. doi: 10.3181/00379727-187-42651

27. Evenson JK, Sunde RA. Time course of selenium labeling of selenoproteins in Se adequate and high Se rats. Fed Proc. (1987) 46:907.

28. Sunde RA, Evenson JK. Metabolism of ${ }^{75}$ Se from $\left[{ }^{75}\right.$ Se $]$ selenodiglutathione into selenoproteins in rats. FASEB J. (1990) 4:A1061.

29. Evenson JK, Thompson KM, Weiss SL, Sunde RA. Metabolism of ${ }^{75}$ Se from $\left[{ }^{75}\right.$ Se] selenate into selenoproteins in rats. FASEB J. (1991) 5:A579.

30. Waschulewski IH, Batley BL, Sunde RA. The effect of dietary methionine on ${ }^{75} \mathrm{Se}$ incorporation from $\left[{ }^{75} \mathrm{Se}\right]$ selenomethionine into selenoproteins. FASEB J. (1988) 2:A1089.

31. Evenson JK, Sunde RA. Metabolism of ${ }^{75} \mathrm{Se}$ from $\left[{ }^{75} \mathrm{Se}\right]$ selenobetaine into selenoproteins in rats. FASEB J. (1990) 4:A372.

32. Kobayashi Y, Ogra Y, Ishiwata K, Takayama H, Aimi N, Suzuki KT. Selenosugars are key and urinary metabolites for selenium excretion within the required to low-toxic range. Proc Natl Acad Sci. (2002) 99:15932-6. doi: 10.1073/pnas.2526 10699

33. Bierla K, Taylor RM, Szpunar J, Lobinski R, Sunde RA. Identification and determination of selenocysteine, selenosugar, and other selenometabolites in turkey liver. Metallomics. (2020) 12:758-66. doi: 10.1039/D0MT9 0015J
34. Lei XG, Evenson JK, Thompson KM, Sunde RA. Glutathione peroxidase and phospholipid hydroperoxide glutathione peroxidase are differentially regulated in rats by dietary selenium. J Nutr. (1995) 125:1438-46. doi: 10.1093/jn/125.6.1438

35. Barnes KM, Evenson JK, Raines AM, Sunde RA. Transcript analysis of the selenoproteome indicates that dietary selenium requirements in rats based on selenium-regulated selenoprotein mRNA levels are uniformly less than those based on glutathione peroxidase activity. J Nutr. (2009) 139:199206. doi: $10.3945 /$ jn.108.098624

36. Ganther HE. Reduction of the selenotrisulfide derivative of glutathione to a persulfide analog by glutathione reductase. Biochemistry. (1971) 10:408998. doi: 10.1021/bi00798a013

37. Foster SJ, Kraus RJ, Ganther HE. Formation of dimethyl selenide and trimethylselenonium from selenobetaine in the rat. Arch Biochem Biophys. (1986) 247:12-19. doi: 10.1016/0003-9861(86)90527-8

38. Raines AM, Sunde RA. Selenium toxicity but not deficient or super-nutritional selenium status vastly alters the transcriptome in rodents. BMC Genomics. (2011) 12:26. doi: 10.1186/1471-2164-12-26

39. Weiss Sachdev S, Sunde RA. Selenium regulation of transcript abundance and relative translational efficiency of glutathione peroxidase 1 and 4 in rat liver. Biochem. (2001) 357:851-8. doi: 10.1042/bj3570851

40. Burk RF, Hill KE, Selenoprotein P. A selenium-rich extracellular glycoprotein. J Nutr. (1994) 124:1891-7. doi: 10.1093/jn/124.10.1891

41. Olson GE, Winfrey VP, Nagdas SK, Hill KE, Burk RF. Apolipoprotein E receptor-2 (ApoER2). mediates selenium uptake from selenoprotein $\mathrm{P}$ by the mouse testis. J Biol Chem. (2007) 282:12290-97. doi: 10.1074/jbc.M6114 03200

42. Janghorbani M, Mooers CS, Smith MA, Hazell T, Blanock K, Ting BT. Correlation between the size of the selenite-exchangeable metabolic pool and total body or liver selenium in rats. J. Nutr. (1991) 121:34554. doi: 10.1093/jn/121.3.345

43. Knight $S A B$, Sunde RA. Effect of selenium repletion on glutathione peroxidase protein in rat liver. J Nutr. (1988) 118:853-8. doi: 10.1093/jn/118.7.853

44. Saedi MS, Smith CG, Frampton J, Chambers I, Harrison PR, Sunde RA. Effect of selenium status on mRNA levels for glutathione peroxidase in rat liver. Biochem Biophys Res Commun. (1988) 153:855-61. doi: 10.1016/S0006-291X(88)81174-4

45. Kobayashi Y, Ogra Y, Suzuki KT. Speciation and metabolism of selenium injected with $82 \mathrm{Se}$-enriched selenite and selenate in rats. J Chromatogr B Biomed Sci Appl. (2001) 760:73-81. doi: 10.1016/s0378-4347(01)00252-3

46. Anan Y, Ohbo A, Tani Y, Ogra Y. Metabolic pathway of inorganic and organic selenocompounds labeled with stable isotope in Japanese quail. Anal Bioanal Chem. (2014) 406:7959-66. doi: 10.1007/s00216-014-8260-3

47. Lu Y, Pergantis SA. Selenosugar determination in porcine liver using multidimensional HPLC with atomic and molecular mass spectrometry. Metallomics. (2009) 1:346-52. doi: 10.1039/b904230j

48. Gonzalez-Iglesias H, Fernandez-Saqnchez M, Lu Y, Menendez SF, Pergantis SA, Sanz-Medel A. Elemental and molecular mass spectrometry for integrated selenosugar speciation in liver and kidney tissues of maternal feeding and supplemented rats. I Anal At Spectrom. (2015) 30:26776. doi: $10.1039 /$ C4JA00248B

49. Takahashi K, Suzuki N, Ogra Y. Effect of administration route and dose on metabolism of nine bioselenocompounds. J Trace Elem Med Biol. (2018) 49:113-8. doi: 10.1016/j.jtemb.2018.05.007

50. Anan Y, Ohbo A, Tani Y, Hatakeyama Y, Yawata A, Ogra Y. Distribution and metabolism of selenite and selenomethionine in the Japanese quail. Metallomics. (2012) 4:457-62. doi: 10.1039/c2mt20013a

Conflict of Interest: The authors declare that the research was conducted in the absence of any commercial or financial relationships that could be construed as a potential conflict of interest.

Copyright (C) 2021 Evenson and Sunde. This is an open-access article distributed under the terms of the Creative Commons Attribution License (CC BY). The use, distribution or reproduction in other forums is permitted, provided the original author(s) and the copyright owner(s) are credited and that the original publication in this journal is cited, in accordance with accepted academic practice. No use, distribution or reproduction is permitted which does not comply with these terms. 